\title{
Iconicidad y autorreflexión implícita en la poesía de Miguel Hernández
}

\author{
ITZÍAR LÓPEZ GUIL \\ Universidad de Zúrich \\ ORCID: 0000-0002-2703-4329
}

\begin{abstract}
Este trabajo se propone demostrar la existencia en la poesía de Miguel Hernández de diversos procedimientos autorreferenciales de carácter icónico con los que crea en sus poemas un segundo nivel de sentido de carácter implícito y metaliterario. Se trata de estrategias que conoce y descubre al lado de Sijé, cuando forma parte de El Gallo Crisis, y que, incluso tras trabar amistad con Neruda y cambiar de poética, seguirá explorando y poniendo en práctica hasta el prematuro e injusto final de su vida.

Keywords: Autorreferencialidad, iconicidad, Miguel Hernández, «Un carnívoro cuchillo», «Umbrío por la pena», «Como el toro he nacido para el luto», «Para la libertad», «Llegó con tres heridas».
\end{abstract}

En memoria de mi querido padre, el pintor y dantista Carlos López Cortezo (1942-2020), que de niña me leía las aún silenciadas «Nanas de la cebolla».

\section{Testimonios y reflexiones metapoéticas}

En los últimos decenios numerosos estudios especializados se han esforzado en desmentir la imagen de poeta intuitivo y espontáneo ${ }^{1}$ que, a me- $^{-}$ nudo, se había achacado a Miguel Hernández. Esta errónea idea probablemente germinó a partir de la «construcción» (Urrutia 20IO: I-6) que el propio Hernández hizo de sí en algunos poemas, cartas y entrevistas tempranas, en los que se autorretrataba como "poeta-pastor», en un ingenuo coqueteo con interlocutores de la talla de Juan Ramón Jiménez, cuya benevolentia probablemente trataba de captar asumiendo una postura modesta (Hernández 2010: I489).

Sin embargo, el poeta oriolano «se planteó de forma disciplinada el aprendizaje de la poesía cuando quiso dedicarse en serio a la escritura» (García Montero 20I8: I86), esto es, tras su primer viaje a Madrid, según demuestran, entre otros, los trabajos de Carmen Alemany Bay (I988, 2004, 2009-20IO, 20IO, 20I2, 20I3, 2018 y 202I), que son resultado de un exhaustivo examen de los borradores y manuscritos del archivo hernandiano. Con tal

I Así lo afirma, por ejemplo, José Carlos Rovira: «uno de los prejuicios más extendidos [...] ha venido siendo el de la "espontaneidad" de Hernández, entendida como "facilidad poética" a la hora de valorar estas composiciones» (Hernández 1985: 35). 
finalidad, nuestro autor realizó un titánico esfuerzo -«con una tenacidad y un entusiasmo dignos de elogio» (Abril 2018: 172)- que se plasmó en muy diversas estrategias de autoinstrucción y ejercitamiento, a saber: además de numerosísimas lecturas, a menudo elaboró previamente en prosa sus propias composiciones, recopiló palabras del diccionario y sus definiciones con el fin de ampliar su vocabulario, copió poemas de otros autores españoles coetáneos como Jorge Guillén, tradujo al castellano a algunos poetas franceses (Verlaine, Mallarmé, Cocteau), hizo listados de rimas, etc. (véase Alemany 2018: 73-76).

Todo este empeño autodidacta naturalmente irá acompañado de diversas reflexiones acerca de la poesía y del poema, reflexiones que jalonan su obra y evolucionan con ella, y que han sido ya examinadas repetidamente por críticos como Balcells (I99I), Cano Ballesta (1972, 1977, 1993, 1996), Aullón de Haro (1993, 1996), Aznar Soler (1996, 2004), la propia Alemany (202I) o, especialmente, Jorge Urrutia (1993, 2004, 20I0), cuyas agudas observaciones acerca del modelo comunicativo hernandiano retomaré después.

Menos atención han merecido las primeras referencias metapoéticas explícitas de Miguel Hernández: aquellas que versan sobre su necesidad irrefrenable de escribir y de superarse en el campo de la lírica; aquellas que descubren la existencia en él de un impulso creador constante, que no cesa, y que le genera sufrimiento y ansia por no conseguir dar con la forma adecuada para sus poemas, según testimonia en varias ocasiones a lo largo de su periplo vital.

\section{I.I. «La poesía es en mí una necesidad» o un rayo que no cesa}

La más antigua de estas referencias se encuentra en una carta a Juan Ramón Jiménez, de noviembre de 1931, donde Hernández se queja de que no puede evitar escribir y emplea la voz chispa ${ }^{2}$ para designar este impulso que identifica con el fuego -en Juan Ramón, dice, es «hoguera»- y que sitúa en el «alma»:

...Por fuerza he tenido que cantar. Inculto, tosco, sé que escribiendo poesía profano el divino arte... No tengo la culpa de llevar en mi alma una chispa de la hoguera que arde en la suya [...] el estado inculto en que me hallo, que no me deja expresarme bien ni claro, ni decir las muchas cosas que pienso (Hernández 20I0: 1489).

Naturalmente, el afamado interlocutor al que se dirige y las circunstancias de quien escribe han de tenerse en cuenta a la hora de evaluar la auten-

2 La naturaleza ígnea de la «chispa» metafórica con la que se identifica este impulso no es, a mi juicio, casual en un escritor que más tarde titulará su segundo poemario El rayo que no cesa. 
ticidad de los sentimientos que expresa el poeta novel. Sin embargo, en dos cartas a Ramón Sijé -la primera de ellas ni un mes posterior a la escrita a Jiménez-, de cuya sinceridad no cabe dudar, Miguel Hernández explicita a quien llama su «hermano [...] en todo» ese sentimiento de insatisfacción constante -en sus palabras, «ansia de superación»y, también, «manía»- en la infructuosa búsqueda de una forma que se ajuste a cuanto desea expresar:

Yo, como siempre, nunca satisfecho de nada de lo que hago. Siempre siento en mí un ansia de superación... ¿Cuándo daré con mi forma? Es mucha mi manía por hallarla. No lo hago por eso. Procuro que lo que diga sea mío nada más. Algún día será que quede libre de extrañas influencias (Hernández 20ı0: I49I; carta fechada en Madrid, I2 diciembre 193I, la cursiva es mía).

Transcurridas unas semanas, confiesa a Sijé las dudas que le acometen acerca de sus capacidades y habla de su condición de poeta como de algo involuntario que forma parte de su esencia, que es intrínseco a su naturaleza («alma de poeta», «ansia de cumbres y soledad de ladera»):

No sé, hermano, no sé. Tan pronto río lleno de alegría, como poseído de una feroz melancolía que arranca lágrimas de mis ojos, me acomete el desaliento; tan pronto creo que lo que hago vale un poquito la pena, como que estoy haciendo el ridículo, me muerdo los puños de rabia e impotencia. ¿Por qué me pusieron un alma de poeta? ¿Por qué no fui como todos los pastores, mazorral, ignorante?... Y este odio al trabajo de los brazos... ¿Y esta ansia de cumbres y soledad de ladera...? (Hernández 20I0: I493; carta fechada en Madrid, II enero 1932, la cursiva es mía).

Permítaseme hacer aquí un inciso, que creo pertinente por la cronología de los hechos. Es bien sabido que Sijé se convirtió en «guía estético» (Urrutia 20I0: I-6) de Hernández a su vuelta de Madrid (véase Urrutia 2004: 98), en el período que escribía su Perito en lunas. Pues bien, en el conocido texto que encabeza este poemario, cuando Sijé habla de la primera luna o fase en la escritura poética de Hernández, identificará el impulso poético inicial con la figura del grito - que ocurrirá con frecuencia en El rayo que no cesa- y le atribuye características propias del rayo hernandiano (su estridencia o sonoridad y su forma puntiaguda):

Cuando la poesía es un grito estridente y puntiagudo -de madrugada en flor fría-, cumple el poeta su primera luna reposada: es el poema terruñero, provincial, querencioso de pastorería de sueños (Hernández 20I0: I83, la letra cursiva es mía). 
En otra carta a Pedro Pérez Clotet de noviembre de 1934, Hernández señala que tiene muchos proyectos literarios y que le gusta el cine porque parece distraerlo de su imaginación, que «siempre» le «atormenta» (el impulso creador, pues, parece no aflojar y seguir siendo una «tortura»):

Tengo en preparación muchas cosas... El cine me atrae irresistible. Yo siempre atormentado por mi imaginación, necesito aliviar un poco este tormento ante el disipar tenebroso. Claro: de las imágenes (Hernández 20IO: 15I4; la cursiva es del original).

Algunos años más tarde, ya durante la guerra, Miguel Hernández escribirá un texto en el que aborda de nuevo aquel impulso, que parece no haber cesado, calificándolo ahora de irremediable «necesidad»e interpretándolo desde una concepción social de la poesía:

Nací en Orihuela hace veintiséis años. He tenido una experiencia del campo y sus trabajos, penosa, dura, como la necesita cada hombre, cuidando cabras y cortando a golpe de hacha olmos y chopos, me he defendido del hambre, de los amos, de las lluvias y de estos veranos levantinos, inhumanos, de ardientes. La poesía es en mí una necesidad y escribo porque no encuentro remedio para no escribir. La sentí, como sentí mi condición de hombre, y como hombre la conllevo, procurando a cada paso dignificarme a través de sus martillerazos. Me he metido con toda ella dentro de esta tremenda España popular, de la que no sé si he salido nunca. En la guerra la escribo como un arma, y en la paz será un arma también aunque reposada.

Vivo para exaltar los valores puros del pueblo, y a su lado estoy tan dispuesto a vivir como a morir (Hernández 20I0: 843; la cursiva es mía).

Bien alejado ya de la naturaleza testimonial y más o menos espontánea de los fragmentos anteriores, nos hallamos ahora ante un texto programático, muy cuidado, que comienza trazando un paralelismo implícito entre el acto enunciativo que lo constituye y la vida del Yo, al hacer coincidir las voces «Nací» $\mathrm{y}$ «morir» con el inicio/nacimiento y el final/muerte del propio texto ${ }^{3}$.

En el primer párrafo se equipara implícitamente la «penosa, dura» «experiencia del campo y sus trabajos» con la poesía, en tanto que la primera

\footnotetext{
3 Según se intentará mostrar en los siguientes apartados de este trabajo, se trata este de un recurso autorreflexivo muy ocurrente en la poesía hernandiana, que ya encontramos en Perito en lunas y que se hará frecuente en su poesía «solar» a partir de El silbo vulnerado y, sobre todo, de El rayo que no cesa. A través de esta identificación entre enunciado y enunciación, entre lo que el texto dice y lo que el texto hace, se consigue instaurar un embrague entre ambos niveles, de modo que se vuelve predicable del poema cuanto se expresa en el enunciado, como se verá más adelante.
} 
«la necesita cada hombre» y la segunda «es en mí una necesidad», un impulso irresistible al cual le es imposible sustraerse (según el DRAE, s. necesidad). Esta homologación convierte en equivalentes las características propias del trabajo del campo y las de la escritura poética, implícitamente considerada una actividad asimismo «penosa, dura»-de ahí que el Yo más tarde señale que la «conlleva»-: una actividad que se realiza porque no se ha «encontrado remedio» para no hacerla, porque no se ha conseguido dar con manera alguna de frenar ese impulso creador atormentante. El primer párrafo se cierra estableciendo un nuevo paralelismo, esta vez entre la forma en que el Yo sintió la poesía y su «condición de hombre», es decir, su condición masculina (indirectamente se homologarían, pues, impulso poético y la manifestación del deseo sexual masculino ${ }^{4}$. Dicha equiparación -que es una personal interpretación a posteriori de su trayectoria poética inicialresulta iluminadora, pues, como me propongo demostrar más adelante, ese rayo que no cesa y que protagoniza su primer poemario «solar» figurativiza, por supuesto, el deseo amoroso, como toda la crítica ha sabido leer; pero, en un nivel de sentido figurado y claramente metaliterario, tal rayo también encarna el impulso poético, tal y como expresa aquí Hernández a través de esta equiparación referida a aquella etapa, para él ya pretérita, de su poesía5. De hecho, en el segundo y tercer párrafos, el Yo aludirá en presente a otra faceta de su creación lírica -la de Viento del pueblo y El hombre acecha-, donde el sentido literal de los poemas no será ya amoroso sino social, si bien el segundo nivel de sentido, implícito, seguirá siendo metaliterario.

A la luz de estos textos no parece desencaminado sostener que ese impulso constante que Hernández sentía, su permanente necesidad de escribir y de superarse, fue el motor que le empujó siempre a perfeccionar su poesía y, en consecuencia, a evolucionar. Este y otros aspectos aledaños a la escritura (algunos de los cuales ya habían empezado a aparecer en Perito), a partir de El rayo que no cesa pasarán a ser tema habitual del nivel de sentido

4 Diversos críticos, como por ejemplo Eutimio Martín (2015), han apuntado en sus trabajos la presencia de metáforas sexuales en la obra hernandiana, especialmente fálicas. Aquí, desde luego, los «martillerazos» (de «martillero», 'subastador') parecen aludir a un tiempo al miembro erecto y, en un sentido metapoético, a los dictámenes del impulso creador (ya que el martillero es quien decreta el valor de las cosas en una subasta). El hecho de que, según el $D R A E$, martillero sea un vocablo de uso casi exclusivo en el Cono Sur, podría apuntar a una influencia léxica directa de Neruda.

5 Esta equiparación se confirma en una carta a Luis Almarcha, fechada el io de octubre de 1932, en la que Hernández afirma que el sentimiento amoroso es el impulso que debe regir tanto las labores del campo como la actividad poética: «Ellos no sabrán nunca que leer y hacer versos e inclinarse sobre la tierra, o sobre las cabras, son la misma cosa y para leer y hacer versos, como para trabajar es necesario (¿verdad?) amor. Y yo hago desde que pude lo que hago y siempre amo, y no hago lo que hice una vez y siempre odio» (Hernández 2010: 1502). 
implícito presente en algunos de sus poemas más conocidos ${ }^{6}$, tal y como se intentará mostrar en lo que sigue.

\section{I.2. El «agónico problema» de la «conversión del "sujeto" en "objeto" poé- tico» y la poética conceptista de Perito en lunas}

I.2.I. Según apunta Agustín Sánchez Vidal, el fracaso de su primer viaje a Madrid pone al hasta entonces intuitivo Miguel Hernández en el disparadero de transformarse o sucumbir, por lo que el joven oriolano empieza a trabajar de forma febril (véase Hernández I976: Io).

Cuando publique Perito en lunas ${ }^{7}$, Miguel Hernández colocará al frente de sus poemas el texto de Sijé ${ }^{8}$ al que nos hemos referido más arriba, concediéndole una posición programática y, por consiguiente, reconociéndose en lo que en él se expone. En este preliminar las tres «lunas» no son «el satélite de la tierra» y Urrutia las interpreta como

período de tiempo, lapso, cada uno de los estadios por los que pasa el poeta, a la manera del poema juanramoniano tan conocido: «Vino primero pura /

6 Aunque Balcells no profundiza en el sentido metaliterario de los textos, sí lo presiente y alude a él brevemente -también en forma de notas en las que remite a la lectura de Sijé- en párrafos como este: «Una de las vertientes dramáticas del libro acontece cuando, como en el supuesto del toro, símbolo hernandiano por excelencia en aquella hora, el corazón se agranda todavía más cuanto más lo castiga el hierro del soneto, y con la penitencia de un estilo en el que la sensación, el sentido y el sentimiento han de doblegarse ante las tarascadas de las delgadeces y apreturas conceptuosas» (Balcells 199I: 8I).

7 En varios trabajos, Urrutia (2004, 20I0) ha explicado certeramente el sentido del título definitivo de este poemario a partir de las nociones teóricas del propio Sijé: el Yo hernandiano sería «perito» o «experto» en la escritura de poemas o «lunas». La metáfora del poema como luna proviene de Le traité du Narcisse de Gide, de donde Sijé toma la noción de «cristalizar» para expresar con ella el acto de convertir la corriente de la poesía en el objeto poema (véase Urrutia 2004: 98). Según Urrutia, «luna» no haría referencia al satélite de la Tierra, sino que tendría la acepción de «espejo», aspecto con el que concuerdo, si bien, en mi opinión, no se debería desechar esa primera acepción más común, que también estaría presente y resultaría complementaria de la propuesta por Urrutia si se tiene en cuenta su condición de astro-espejo de la luz solar.

8 «Cuando la poesía es un grito estridente y puntiagudo - de madrugada en flor fría-, cumple el poeta su primera luna reposada: es el poema terruñero, provincial, querencioso de pastorería de sueños. // Cuando es aterradora la pregunta "La poésie est elle dépendante de la poétique? ou poétique et poésie, du poème?”, nace el religioso albor de su segunda luna: poesía literaria, resonante de voces y reflejos, con fundadora alegría de romancero entrañable; obra conseguida con mínimos "elementos", con mínimo "esfuerzo". // Cuando el poeta es recta unidad y torre cerrada, cruza, pariendo, su tercera luna: es el poema de rito inefable, producto de "la acción transformante y unificante de una realidad misteriosa", es la estrella pura, en delirio callado de tormentas deliciosas. // Miguel Hernández (nacido el 30 de octubre del año de gracia poética de I9I0, en Orihuela, lugar situado a $50 \mathrm{~km}$ de Alicante, a 20 de Murcia), ha resuelto, técnicamente, su agónico problema: conversión del "sujeto" en "objeto" poético. Porque la poesía -y "su poesía”, con musculatura marina de grumete- es tan sólo, transmutación, milagro y virtud» (Hernández 2010: I83). 
y la amé como un niño...». Pero también es posible entender que se refiere a la materialización del poema: cumple la primera, produce el nacimiento del albor de la segunda y cruza y pare la tercera (Urrutia 2004: 99).

Navegando entre ambas opciones, está mi propuesta de su lectura como las tres progresivas fases en el trabajo y perfeccionamiento del impulso poético, de la poesía: dependen del grado de reflexión y esfuerzo del poeta, y se materializan en sendos tipos de poema (de menos a más perfecto). La primera luna es «reposada» porque la «cumple» o ejecuta el poeta al escribir un poema de forma intuitiva; un poema que es cristalización de un impulso («un grito estridente y puntiagudo», como el rayo) y no entraña trabajo o reflexión alguna (por eso es una luna «reposada» o descansada). La segunda luna ya incluiría la asunción de cierta reflexión teórica -representada en la reproducción de la pregunta que formula retóricamente Henri Bremond en La poesía pura (1926) - aunque desde una concepción todavía sacralizada de la poesía (de ahí el «religioso albor»). Se trata de una «poesía literaria» que cristalizaría en un poema conseguido con «mínimos elementos, con mínimo esfuerzo». Las reflexiones del poeta son -según Sijé- «mínimas», puesto que todavía no ha encontrado su propia voz (es una poesía «resonante de voces y reflejos») y le resulta «aterradora» la pregunta de Bremond, para la que no halla aún respuesta (vendría a ser la fase en la que estaba Miguel Hernández en su primer viaje a Madrid, como vimos en el apartado anterior, cuando en carta a Sijé señalaba su anhelo de quedar «libre de extrañas influencias»). Ahora bien, para atravesar la tercera luna y parir un poema -y nótese que el verbo designa dar a luz un ser vivo- es necesario que el poeta se transforme: que se convierta en «recta unidad» $y$ «torre cerrada», dos figuras que remiten, respectivamente, a los conceptos sijeanos del poema como cristalización geométrica ${ }^{9}$ y de la poesía pura de carácter hermético. En esta tercera fase hay que situar los textos de Perito en lunas, al decir de Sijé, que Hernández ha conseguido llegar a «parir» tras resolver «técnicamente ${ }^{10}$ su «agónico problema». Como bien ha señalado Urrutia, a lo que se está aludiendo aquí -y en ello se cifra el origen de un poema vivo, parido- es a la «transmutación», a la «conversión del "sujeto" en "objeto" poético»; esto es, para que el poema tenga vida propia - a diferencia de aquellos surgidos de las dos lunas anteriores- ha de morir el sujeto, ha de «transmutarse» en objeto/poema. Por eso, a mi juicio, «agónico» actualiza aquí, a un tiempo,

9 En su «Prólogo» a La decadencia de la flauta y el reinado de los fantasmas de Sijé, Martínez Galiano resume así varios conceptos sijeanos: «Llama cristalización, a la identificación unitaria de contenido y forma; cristalizar, a transformar la vida y la realidad en poesía; cristal, al objeto poético como participación de la realidad y de la persona, como sucedáneo imaginativo de la realidad, como cristalización de la realidad en una palabra; cristales, a palabras y versos puros de belleza objetiva y absoluta» (Sijé 1973: 3I).

Io De ahí que sea «perito», como acertadamente sostiene Urrutia (2004, 2010). 
sus dos acepciones más comunes: la de lucha (pues conseguir esa distancia estética no le ha sido fácil a Hernández) y, además, la que hace referencia al estado de agonía, ya que el sujeto biográfico ha de morir simbólicamente y convertirse en sujeto poético (en el objeto-poema). Cuando se produce esta transmutación, el poema vivo es una «estrella pura», emite luz propia y no está contaminado con otras «voces» (como el poema que surge de la segunda luna). Además, Sijé describe el poema nacido de esta tercera luna mediante oxímoros («delirio callado», «tormenta deliciosa»)" escaparía, por tanto, a la lógica racional e impondría la suya propia, que es «misteriosa». Permítaseme observar que esta concepción de Sijé -y, por consiguiente, la de Hernández- es muy similar a la que promulga García Lorca en 1928 respecto al poema fruto de la «inspiración» (véase García Lorca I977a: I067-69), que también sería la tercera y última etapa, según el poeta granadino, dentro de la escala de la creación poética: su efecto es la evasión (de la lógica racional) y el «duende», su mejor cualidad. Como es sabido, para Lorca el duende «está intensamente relacionado con el aspecto innovador del arte poético, con la muerte y con lo sobrenatural» (López Guil 20I6: 22) ${ }^{12}$. La muerte, pues, posee un claro significado metaliterario tanto para Lorca como para Sijé, significado que también encontramos ya en algunos poemas de Perito, sin ir más lejos en su primera y su última octavas.

El poema I de Perito llevaba el título de «Suicida en cierne»"13 que, en el nivel literal de sentido, como acertadamente prueba Sánchez Vidal (Hernández I976: 82-84), alude a la próxima caída de un higo maduro al suelo ${ }^{14}$. Pero, implícitamente, el texto está evocando la citada transmutación sijeana, que es siempre una especie de suicidio simbólico, de conversión de lo vital en objeto de arte, en algo muerto que finge vida. De ahí que la voz poética se identifique con este «higo» ya maduro, porque también ella ha alcanzado un cierto grado de madurez (es perita) y puede comenzar a ope-

II El oxímoron tradicionalmente se ha asociado a la poesía por ser figura retórica capaz de cumplir una de las funciones primordiales del poema que es nombrar lo inefable, como el propio Sijé señala en su texto («poema de rito inefable»).

I2 Tanto Sijé como Lorca apelan, en la que consideran tercera y más perfecta fase de la poesía, a un proceso de muerte de carácter metafórico, relacionado con la lógica poética y con la transformación del sujeto biográfico en sujeto poético.

I3 «(Suicida en cierne) // Je m'enfonce au mépris de tant // d'azur oiseux // VALERY // A lo caña silbada de artificio, / rastro, / si no evasion de su suceso, / bajaré contra el peso de mi peso: / simulación de náutico ejercicio. / Bien cercén del azar, bien precipicios, / me desamparará de azul ileso: / no la pita, que tal vez a cercenes / me impida reflejar sierra en mis sienes» (Hernández 1976: 82).

I4 Esto lo deduce Sánchez Vidal de este otro poema de la misma época, algo más explícito: «HIGOS - sazón y hojas // En verdes paracaídas / cuelgan, como negras horas, / sus coincidencias medoras / deleitaciones suicidas. / Por su sazón requeridas, / las armas de los deseos / a amparar los titubeos / ascienden, mas tan ronceras / que ya las ropas primeras / suicidios llueven guineos» (Hernández 1976: 84). 
rar esa transubstanciación suicida. El sintagma «en cierne» ('estar en sus principios', según el $D R A E$ ), antes de ser eliminado, fungía de embrague entre el sentido literal y el figurado, puesto que constituía el inicio del poema y del propio libro y, por consiguiente, establecía un paralelismo entre el enunciado (un suicida entrando en acción) y la enunciación (un poema y un libro comenzando) ${ }^{15}$. Al eliminar el título, Hernández hace desaparecer toda evidencia del embrague y también la clave de lectura, conforme a los postulados de Sijét ${ }^{16}$, si bien, en el cuerpo del texto, se sigue evocando ese movimiento de descenso que alude tanto a la caída del higo como a la dirección seguida por la pluma/ojos durante el cifrado/desciframiento del poema (lectura que apoya el hecho de que el higo/suicida hable en primera persona $)^{17}$.

I5 El texto va precedido por dos versos de Paul Valéry, uno de los mayores representantes de la poesía pura en Francia en aquella época, que pertenecen al poema «El remero». Se trata de una composición claramente metaliteraria en la que la actividad de creación poética se asocia implícitamente al remar del Yo. Lo interesante es que, en este poema de Valéry, los espacios con los que normalmente se identifican trascendencia e inmanencia (cielo y río, respectivamente), aparecen aquí asociados al concepto inverso: el cielo, a la vida humana (que se refleja en el río donde rema el Yo, actividad relacionada con la creación poética). En el verso final que cita Hernández («me sumerjo a pesar de tanto azul ocioso»), el remero decide sumergirse en la oscuridad de los arcos de los puentes (que probablemente evocan las pausas interestróficas y, en la última ocasión, el espacio blanco final donde, al acabarse el poema, el Yo se sumerge y desaparece). En nuestro poema hallaremos esta misma introducción de una distancia entre el Yo y el cielo azul representada con un movimiento descendente de alejamiento, y que alude, en un sentido implícito, al movimiento que siguen mano y ojos sea al escribir el poema, sea al leerlo (tanto pluma como mirada realizan un movimiento descendente a medida que avanzan en la escritura/lectura del poema: como veremos más adelante, Sijé era plenamente consciente de este movimiento y a él apela en sus escritos de El Gallo Crisis).

I6 La eliminación de claves en Góngora es admirada por Sijé: «Claridad poética es cristalinidad. Un verso de Góngora es claro; contiene todas las cualidades necesarias para que se produzca la claridad, porque es un cristal, porque es un objeto. Un verso de las Soledades es claro; las Soledades, consideradas como unidad de poema, ya no son tan claras; o, mejor dicho, tienen una claridad que nuestros ojos no pueden comprender. El Conquistador quemó las naves; España continuaba existiendo, pero no como posibilidad de vuelta inmediata. Pues bien, el poeta, como antes decía, ha quemado las claves. El objeto poemático es perfectamente cristalino, se pasa de objetivo, pero falta la llave que nos permita la entrada, el sistema de palabras que ha servido de modelo para la creación del lenguaje plástico» (Urrutia 2004: IOO-IOI). I7 La interpretación de este primer poema de Perito, sería, a mi juicio, la que expongo a continuación. Como la caña del cohete (rastro de su estallido), voy a bajar «contra el peso de mi peso» (contra la gravedad de mi peso). Con respecto al significado de «simulación de náutico ejercicio», la crítica interpreta esta metáfora como el salto de un nadador que se zambulle en el agua, si bien el adjetivo «náutico» significa 'relativo a la navegación' (y zambullirse no es navegar). Creo que podría estar haciendo referencia al poema de Valéry, concretamente al movimiento del remo en el agua (pues remar sí es un ejercicio náutico): el higo/el Yo-poema cae como el remo se introduce en el agua, haciendo que el barco avance por la corriente, de estrofa en estrofa. Ya sea un corte del azar, ya sea una caída como de precipicio, cualquiera de las dos cosas me desamparará de estar intacto en el cielo. No me desamparará la pita, que quizá con sus cortes o cercenes impedirá que yo «refleje sierra en mis sienes». Este verso es bien difícil de desentrañar: algunos críticos como Sánchez Vidal entienden por pita los cristales que hay sobre la tapia del huerto impidiendo que se pueda escalar por ella. Pero Hernández nunca 
También el cierre de Perito alude al fenómeno de la transmutación (y a la pita), a juzgar por el embrague de los versos finales de la octava XLII, donde el Yo-que era un suicida en ciernes en I- ahora queda muerto, coincidiendo con la muerte del poema y del poemario, esto es, con su final ${ }^{18}$ :

\section{XLII}

\section{(GUERRA DE ESTÍO)}

¡Oh combate imposible de la pita con la que en torno mío luz avanza! Su bayoneta, aunque incurriendo en lanza, en vano con sus filos se concita; como la de elipsoides ya crinita, geométrica chumbera, nada alcanza: lista la luz me toma sobre el huerto, y a cañonazos de cigarras muerto.

En el sentido literal, este poema tematiza la victoria de la luz del cielo sobre el Yo y el combate simbólico con ella del árbol de la pita, cuyos

usa pita explícitamente con este valor. En un poema de esta misma época las pitas aparecen en la tapia, pero no sobre ella: «TAPIA DEL HUERTO-MÍO // [...] Entre los niños de afuera, / por necesidad ladrones, / y las guineas facciones / del higo de puro escritas / la tapia, a fuerza de pitas, / dividiendo está opiniones» (Hernández 1976: 83). En cambio, en el último poema de Perito aparece con su acepción de 'árbol del agave', que es el sentido que creo posee también en este primer poema, según recoge la edición del DRAE de 1927: «Pita: [...] Es muy útil para hacer setos vivos en terrenos secos y cálidos; se ha naturalizado en las costas del Mediterráneo. De las hojas se saca buena hilaza». Los muros de los huertos estaban guarnecidos con pitas cuyas lanzas, con sus filos, protegían los frutos. En un sentido implícito y metaliterario, si el azar o el precipicio desampararán al «suicida» del azul ileso, no así «la pita, que tal vez a cercenes / me impida reflejar sierra en mis sienes». La pita, cercenando al higo al caer, tal vez impida que mis sienes reflejen sierra/nieve/edad, es decir, que madure. En un sentido figurado, los versos, cercenando la hoja, tal vez eviten que envejezca, tal vez logren mi inmortalidad (pues la pita, además de tener forma lineal como el verso, tiene una hilaza de la que se hacían tejidos/ textos); en el sentido literal, el árbol de la pita, si me cercena al caer, impedirá que mis sienes blanqueen porque maduren, ya que el higo se vuelve blanquecino cuando madura, hecho que se describe en esta otra décima de la época: «HIGO-desconocido // Por su desconocimiento / de nadie, nadie lo toma; / nadie lo desea exento / de su viso y de su aroma. / Con la madurez, asoma / el faldón por la sotana. / Y sólo la avispa hircana, / menoscabando etiopía, / demuesta la anatomía / de su luto arrope y grana» (Hernández 20I0: 23I).

I8 Este embrague es muy parecido a aquel con el que García Lorca -tan admirado por Hernández- cierra su Romancero gitano: «Los versos finales del poemario [...], al hacer coincidir enunciado y enunciación, obligan a una lectura autorreferencial del libro, puesto que tanto el "Romance de Thamar y Amnón" como el propio Romancero finalizan al tiempo que, tras la huida de Amnón, la instancia de la narración señala cómo David rompe su arpa y, consecuentemente, cesa el canto (de modo que los cuatro cascos remiten a los cuatro versos de la estrofa que se "corta", que acaba tras haber "resonado" los cuatro versos)» (López Guil 20II: 98). 
filos en vano se concitan ${ }^{19}$, es decir, incitan a la sedición, a rebelarse contra esa luz. Nada logran ni la pita ni la geométrica chumbera, con su crin de elipsoides, porque la luz vence al Yo en el huerto y lo encuentra muerto por los cañonazos de las cigarras. Teniendo en cuenta que es el último poema y que coincide con el final del libro, nos encontramos ante otro embrague textual, dado que poema y libro mueren cuando el Yo, que es el sujeto, ya se ha transubstanciado en poema (por eso ha muerto a manos de las cigarras, emblema del cantor despreocupado estival frente a la hormiga y su previsora lógica). Esa «luz en torno mío» que, literalmente, alude a la claridad del cielo, tiene también un sentido claramente metapoético y evoca el blanco de la hoja que rodea a este poema-Yo ("en torno mío luz avanza»), contra la que combate la pita inútilmente ${ }^{20}$. Como veremos inmediatamente, la victoria final de luz sobre el Yo es una clara referencia al efecto lumínico del arte, que Hernández, en esta época, considera una de sus máximas virtudes.

I.2.2. Con respecto a la poética neogongorina de Perito en lunas, conviene examinar, además, «Mi concepto de poema $»^{21}$, un texto de 1933 , en el que la definición que ofrece Hernández posee la forma de un diálogo ${ }^{22}$ entre «el lector» $\mathrm{y}$ «el poeta»; un diálogo en el que «el lector» inquiere y «el poeta»,

I9 DRAE, s. concitarse: «Excitar inquietudes y sediciones en el ánimo de los demás».

20 Otra vez su forma lineal se emplea para establecer una equivalencia entre su contraste contra el cielo y el de los versos contra el luminoso espacio blanco de la hoja. Recuérdese a Sijé a este propósito, tanto en su estimación del triunfo de la claridad en la poesía de Góngora, como en lo tocante al poema parido en esa tercera luna, cuando el poeta es "torre cerrada", como la pita, el árbol del agave «cerrado» alrededor por las hojas con púas.

2I [A] «QQué es el poema? El poeta: Una bella mentira fingida. Una verdad insinuada. Sólo insinuándola, no parece una verdad mentira. Una verdad preciosa y recóndita como la de la mina. Se necesita ser minero de poemas para ver en sus etiopías de sombras sus indias de luces. Una verdad de la sal en situación azul y cantora. ¿Quién ve la marina verdad blanca? Nadie. Sin embargo existe, late, se alude en el color lunado de la espuma en bulto. El mar evidente, ¿sería tan bello como en su sigilo si se evidenciara de repente? Su mayor hermosura reside en su recato. El poema no puede presentársenos Venus o desnudo. Los poemas desnudos son la anatomía de los poemas. ¿Y habrá algo más horrible que un esqueleto? [B] Guardad, poetas, el secreto del poema: esfinge. Que sepan arrancárselo como una corteza. ¡Oh, la naranja: qué delicioso secreto bajo un ámbito a lo mundo! Salvo en el caso de la poesía profética en que todo ha de ser claridad -porque no se trata de ilustrar sensaciones, de solear cerebros con el relámpago de la imagen de la talla, sino de propagar emociones, de avivar vidas-, guardaos, poetas, de dar frutos sin piel, mares sin sal. Con el poema debiera suceder lo que con el Santísimo Sacramento... ¿Cuándo dirá el poeta con el poema incorporado a sus dedos, como dice el cura con la hostia: "Aquí está DIOS” y lo creeremos?» (Hernández 20I0: 732; las letras A y B entre corchetes son mías).

22 «Mi concepto de poema» será corregido posteriormente y en su forma definitiva se elimina la forma de diálogo (probablemente para salvar la incoherencia de que pregunte el lector y el Yo, en su respuesta, se dirija a los poetas, en vez de a quien le pregunta). En la version final la pregunta «¿Qué es el poema?» es solo retórica, no hay una dramatización con dos personajes, sino que el desdoblamiento se produce en la misma entidad enunciadora, en la voz que habla: se pregunta y se responde a sí misma, simulando el acto reflexivo previo del que es fruto ese «concepto» del título. 
que detenta el saber, contesta. Su respuesta tiene dos partes claras: en la primera (que llamaré A y comprende desde el inicio hasta «¿Y habrá algo más horrible que un esqueleto?»), se define el poema y, en la segunda, B (desde «Guardad, poetas» hasta el final), el Yo simulacro del poeta se dirige a otros posibles colegas de oficio, conminándolos a seguir la poética que propone.

En A se responde a la interrogación con dos definiciones aparentemente antónimas que, sin embargo, por referirse ambas al poema, resultan homologables: «Una bella mentira fingida. Una verdad insinuada». Adviértase cómo la similar construcción sintáctica de ambos sintagmas favorece dicha equiparación, convirtiendo en equivalentes «bella mentira» $\mathrm{y}$ "verdad» $»^{23}$. La cualidad estética de la mentira nos pone en guardia sobre el tipo de verdad a la que equivale: no se trata de una verdad referencial, sino de una verdad literaria, estética. Según recalca María Moliner en su definición ${ }^{24}$, un rasgo importante de la mentira, además de su naturaleza falsa - de su falta de coincidencia con la verdad-, es su finalidad persuasiva. La mentira pretende hacer creer, al igual que la verdad estética o literaria, que no es sino el «efecto de un arte persuasivo, capaz de provocar en el ánimo del lector una [...] vivencia de la lectura, que cuaja en una verdad creída [...] que comunica por medio del lenguaje vívidas impresiones, sentimientos, pasión»(Güntert 2006: 202). Los dos participios - «fingida» e «insinuada»- hacen referencia al modo en el que esa bella mentira o esa verdad estética se comunican y, en el caso del participio que acompaña a «bella mentira», se insiste de nuevo en la persuasion, ya que fingir es «Dejar ver o hacer creer con palabras, gestos o acciones algo que no es verdad» (Moliner, s. fingir). Insinuar, sin embargo, añade el sema 'falta de claridad' en el modo de expresión ${ }^{25}$. La siguiente frase recalca precisamente este aspecto: la falta de claridad incide en el pacto de veridicción, porque solo «insinuándola, no parece una verdad mentira». A partir de aquí, buena parte de A tematizará la interdependencia entre la oscuridad expresiva y el efecto lumínico del arte, su veridicción exitosa y su belleza. En su tercera ocurrencia, sin embargo, «verdad», modificada por «preciosa y recóndita», actualiza también su acepción más común, esto es, la de verdad referencial (o existencia de una correspondencia entre la representación verbal y el objeto extratextual representado). Y así, según este texto, el poeta y el lector, quienes cifran y descifran el poema, han de encontrar estas correspondencias, han de ser «un

23 Naturalmente no se trata de una definición original de Hernández, sino que en ella hay ecos de toda una tradición literaria (por ejemplo, del Marqués de Santillana en su Carta-Proemio al condestable de Portugal) que bebe de la definición que Dante ofrece de la alegoría poética al inicio del «Tratado II» del Convivio («una veritade ascosa sotto bella menzogna», Alighieri 1993: 902).

24 Véase Moliner, s. mentira: «Cosa que se dice sabiendo que no es verdad, con intención de que sea creída».

25 Véase Moliner, s. insinuar: «Decir una cosa dejándola entrever pero sin expresarla con claridad». 
minero de poemas que vea la luz en la oscuridad», que vea «en sus etiopías de sombras sus indias de luz». De esta frase me parece necesario destacar: a) la metáfora del poema como una piedra preciosa, tal vez un diamante, que es un poliedro (primer título de Perito en lunas); b) que la cualidad estética del poema se haga depender de la oscuridad con la que se insinúe esta verdad, cuya «mayor hermosura reside en su recato». O lo que es lo mismo: que el poema sea más bello cuanto más difícil es de entender. Por el contrario, «Los poemas desnudos son la anatomía de los poemas. ¿Y habrá algo más horrible que un esqueleto ${ }^{26}$ ?». De este modo, nos encontramos ante una barroca y cerebral poética del ingenio ${ }^{27}$, en la que, como bien señalaba Gerardo Diego ${ }^{28}$, la lectura consistirá en descifrar la agudeza revelada por el poema, realizando la operación contraria a la de cifrado o escritura poética.

Si hasta ahora Miguel Hernández había empleado el campo semántico de la minería como metáfora de lo intrincado que ha de ser el sentido del poema, el segmento A se cerrará empleando toda una isotopía marítima para, a través de ella, expresar la oculta presencia de la verdad (la sal) en el poema (que, además, se homologa con el mar por tener en común con él su temporalidad cíclica). En B se alude al misterio poemático con una comparación expresa con el de la comunión ${ }^{29}$ : implícitamente, la verdad de la poesía se asimila a Dios, mientras que, de forma explícita, el poema se equipara a la hostia, el poeta al cura, y el acto de lectura a la misa. En este segundo segmento discursivo también se insiste en la obligación del poeta de velar «el secreto del poema», de modo que el lector sepa «arrancárselo como una corteza», porque, a diferencia de la poesía profética, lo que el simulacro de poeta dice que busca es «ilustrar sensaciones»; y, más significativamente aún, «solear cerebros con el relámpago de la imagen de la talla», donde

26 Aun cuando el original le atribuye un valor diferente, veo en el empleo de Hernández de la voz esqueleto para referirse a un poema desnudo de ingenio, ciertas reminiscencias de la poética de Bécquer, pues, como es sabido, con tal término describía la aridez del poema respecto de la poesía, ese mundo brillante y etéreo que, según el autor de las Rimas, el poema tan solo muy pobremente acierta a reproducir y es por eso considerado su esqueleto (véase Bécquer 1970: 23-32).

27 En el más gracianiano sentido de la palabra ingenio, además, pues, como en el conceptismo, se hace depender la cualidad estética del texto, su «hermosura», de esta herramienta del entendimiento.

28 «No es esencialmente creada la poesía de Perito en lunas... De donde se deduce que para gozarla plenamente hay que entenderla, y, para entenderla, hay que saber recrear en sentido inverso el sendero recorrido por el poeta. Si no, nos quedamos a oscuras, aunque nos halague el juego de imágenes que, borrosa su identificación metafórica, se nos quedan en gratuitas imágenes vagamente sugeridoras y verbales... No creo que haya un solo lector, que los hubiera en 1933 tampoco, capaz de dar la solución a todos los acertijos poéticos que propone» (Diego I960: 27).

29 También Sijé se vale a menudo del misterio de la comunión a la hora de teorizar sobre poesía; por ejemplo, al explicar «la conversión de la poesía en objeto» sosteniendo que consiste en encerrar en el «sagrario» del soneto el tiempo y el espacio (1935: 46). 
«talla» puede referirse tanto a la escultura como al diamante tallado o poliedro (primer título de Perito). Nótese, además, que, para evocar el contagio poético, la comunicación con «el lector», se emplea la palabra «relámpago», sinónimo de rayo. La poética de Miguel Hernández se adentra en el neogongorinismo, asimilando el ingenio y la oscuridad como bandera de su forma de entender la poesía, en la que adopta una técnica imaginística ${ }^{30}$. Pero es que, además, esta última parte del texto pone de manifiesto que su concepto sacralizado del arte poético, del poema y del poeta se mantiene intacto. Y es que, a mi juicio, Miguel Hernández ahondará en el neogongorinismo precisamente como forma de refrenar y «tallar» su desbordante impulso creador, un impulso cuya extremada intensidad, al no aflojar, probablemente propició que, de acuerdo a la ideología de Sijé, durante mucho tiempo lo asimilara a un don casi sacral, trascendente ${ }^{31}$.

\section{I.3. La poética solar de El rayo que no cesa: la iconicidad y el doble nivel de sentido en los poemas}

El primer triunfo ‘técnico’ de Miguel Hernández, esa diferenciación entre el sujeto biográfico que escribe el poema y el sujeto poético que lo protagoniza, trae aparejada la distancia estética, que posibilita la concepción del poema como un texto de ficción y no como un espacio para la confesión, lo que permitirá a Hernández avanzar hacia otro tipo de complejidades textuales, especialmente en lo tocante al sentido poemático. $\mathrm{Si}$, en un primer paso -representado por la poética neogongorina de Perito en lunas-, creerá firmemente en que la belleza de un poema consiste en que su significado literal sea recóndito y difícil de desentrañar (poética lunar), un poco más

30 Le interesan las metáforas, las imágenes complejas, como a los poetas del 27 en su primera etapa, solo que, por desgracia para Miguel Hernández, él llega a esta fase cuando ellos ya la han abandonado, cuando a Lorca ya no le interesa Góngora.

3I En «Fórmulas», un texto de la misma época, Hernández ofrece la receta de cómo escribir un poema: con respecto a «Mi concepto de poema» ha habido un distanciamiento, propiciado por la técnica que ahora le permite explicar el proceso creativo. Pero el punto de partida es un estado «en trance de ángel» por parte del poeta desde el cual se ha de ofrecer el «patrón exclusivamente único que tenga él de las cosas». Trascendencia e individualidad, aun cuando la técnica se pueda y se deba adquirir, seguirán teniendo un considerable peso:

«FÓRMULAS (De poesía) // Poema-Colóquese el poeta ante las cosas, en trance de ángel, crisis de hombre. Cotéjelas con el patrón exclusivamente único que él tenga de las cosas, y apodérese de éstas para crearlas otra vez, presentándolas bajo el carácter de su ilustración inesperada. Cuando el todo de sensaciones producidas haya dado algunos, ¡bastantes! hervores de gozo y agonía, viértalo, redundando de su vida, de su suceso interno, continuo, espumado a menudo, exento de su desencanto, al recipiente -y músico del verso formal- propende a derramarse de otro modo; agregándole una porción de recato, como de sal en situación corriente y azul verde, aunque otra de alusión a su verdad, como espuma. Propague sospechas entonces de que dentro de aquella presencia de hostia está Dios, el Principio de la creación, accidente suyo, después de lo cual puede servirlo» (Hernández 20I0: 743-44). 
adelante se inclinará por un nivel literal de sentido accesible a cualquier lector (poética solar). Ya en agosto de 1933, refiriéndose a los poemas de un primitivo Silbo vulnerado, Hernández escribe a Pedro Pérez Clotet:

Estoy acabando mi segundo libro para enviarlo [sic] a octubre al Concurso Nacional. Definitivo original. Poemas de factura clásica. Al revés de Perito en lunas, este es un libro descendido y descendiente del sol, solar. Claro y concreto [...] (Hernández 20I0: 15I0).

Esta claridad y concreción del sentido literal - que estaban reservados solo a la poesía profética en «Mi concepto de poesía» y que, entre I933 y I934, Hernández ensaya en textos de temática religiosa como los Silbos-, no excluye que el poeta oriolano siga explorando las posibilidades de ese segundo nivel de sentido implícito a la par que se ejercita en el soneto, especialmente durante el año 34. En esta época, compartía con Sijé la concepción sobre esta forma métrica que, un año más tarde, José Marín expone en un artículo dedicado a la poesía de Alberti en los números 5-6 de El Gallo Crisis:

En el soneto hay un drama: el drama de la personalidad del poeta esclavizada, sirviendo al tiempo y al espacio. En el soneto se oye como un toque de campanas sobre los vidrios del tiempo. La libertad del poeta adquiere, pues, un tono dramático en el intento de objetivación -de finalidad- de la poesía. Porque la conversión de la poesía en objeto consiste en encerrar en el sagrario del soneto -o en otro tipo poético tridimensional: en el soneto hay una formación genética de cubo- el tiempo y el espacio: el alma y la nada. Es difícil, por esta razón, entrar en el soneto -o en la forma geométricamente pura- por el camino del sujeto - de la poesía romántica, de la poesía abiertase llega a la nada: y por el camino del objeto, al alma (Sijé i935: 46).

La insistencia de Sijé en la tridimensionalidad del soneto y de otros «tipos poéticos» parece aludir a esa forma de iconicidad de la que se valdrá después Miguel Hernández para construir el segundo nivel de sentido de sus textos. Una iconicidad que, a menudo, nace de la institución de un paralelismo espacial o temporal entre el enunciado y la enunciación (entre lo tematizado en el soneto y algunos aspectos espacio-temporales de la forma métrica), como hace Sijé en este texto:

El alma ha creado el hijo: el objeto que puede llamarse soneto. [...] La mano puede percibir la plenitud de objeto acabado, y acariciar los lomos de sus aristas. [...] catorce versos y una puerta. [...] Catorce puñaladas en la soberbia del poeta es el soneto. Debe hablarse, por lo tanto, de un arte humilde de hacer sonetos: porque se llega por las escalas del soneto, por los grados de la humildad, a la belleza pura; o aún más, se desciende de la belleza pura -que vive cristalinamente en el primer verso- a la más pura humildad (Sijé I935: 46-47). 
Aquí Marín establece una equivalencia explícita entre la forma cúbica del soneto, con sus catorce versos uno bajo el otro, y una casa (de modo que la puerta de la casa lo es del sentido figurado, oculto, del soneto: de ahí que unas líneas antes considere un sagrario al soneto); o entre los versos y las «puñaladas», donde la agudeza se funda en la forma longitudinal del verso y aquella de la herida producida por el puñal; o entre la dirección descendente de los peldaños de una escalera y la que se sigue, verso a verso, en la escritura/lectura. El grupo de El Gallo Crisis, pues, era muy consciente de las posibilidades semióticas, en especial autorreflexivas, que ofrece la naturaleza icónica o plástica del poema. De hecho, Hernández en varios de los sonetos del Silbo y, luego, del Rayo, instituirá, por ejemplo, una equivalencia implícita entre el verso y la espada de un torero, o entre el color negro del toro y el de la tinta del poema (que, a su vez, es el fruto del tizne del rayo). Lo que no admitía Sijé es que este tipo de iconicidad fuera posible en la poesía «abierta», en la poesía romántica, que detesta también por su 'impureza' sentimental y por creerla poesía del «sujeto» o poesía-confesión y carente de «estilo».

Un ejemplo temprano e inequívoco de iconicidad, aunque practicado en otro tipo de estrofa, es el que, sin duda, se produce en «El silbo de la llaga perfecta $\aleph^{32}$, donde la coincidencia del inicio del poema con la apertura de la llaga y del final de la composición con el cierre de la herida establece una evidente identidad entre el texto y el cuerpo del Yo, entre la exclamación «iAy!» y la llaga tematizada. De este modo, lo predicado de la llaga -que es un espacio por el que salen las «malas ansias» del Yo y en el que sus ojos se convierten en «pozos quietos»- se vuelve también predicable del poema. Esta equiparación homologa la situación enunciativa del texto con aquella escenificada en él, a Dios con la instancia enunciadora, el cuerpo del Yo penitente con el poema (se pone en escena, pues, la transmutación sijeana en objeto poético), etc.

Esta composición forma un conjunto con otros dos «Silbos» que lo preceden y siguen en las Obras completas, «El silbo del dale» $\mathrm{y}$ «El silbo de las ligaduras», respectivamente. Los tres textos están escritos en pareados heptasílabos de rima asonante, estableciéndose de forma implícita una relación entre la forma métrica elegida -arte menor, estrofas breves, un poema visualmente alargado- y el elemento común a los tres títulos, a saber: el «silbo» ${ }^{33}$. Porque el aspecto de los tres poemas sobre la caja tipográfica emula de

32 «El silbo de la llaga perfecta // Ábreme, amor, la puerta / de la llaga perfecta. // Abre, Amor mío, abre / la puerta de mi sangre. // Abre, para que salgan / todas las malas ansias. // Abre, para que huyan / las intenciones turbias. // Abre, para que sean / fuentes puras mis venas, // mis manos cardos mondos / pozos quietos mis ojos. // Abre que viene el aire / de tu palabra... ¡abre! // Abre, Amor, que ya entra... / ¡Ay! // Que no se salga... ¡Cierra!» (Hernández 20I0: 317). 33 Hernández sigue a Sijé, para quien el silbo o silbido es símbolo de la expresión sencilla 
forma plástica la continua y, por tanto, alargada corriente de aire que forma el silbo, ese sonido «agudo que resulta de hacer pasar con fuerza el aire por la boca con los labios fruncidos» (DRAE, s. silbo). A la luz de la lectura figurada del segundo poema, el final del primero ${ }^{34}$, muy similar, también abre al lector la posibilidad de identificar un segundo nivel de sentido: la exclamación «jay!» literalmente expresa el sentir del Yo ante la intervención de $\operatorname{Dios}^{35}$ perfeccionando su alma, según se ha dicho en la estrofa 7 (nótese que con tal número tradicionalmente se cifra la totalidad, las tres personas de la divinidad más los cuatro elementos). Ahora bien, al hacer coincidir el logro de la perfección del alma con el final del poema, implícitamente se establece una equivalencia entre la perfección espiritual evocada en el enunciado y la enunciación acabada, perfecta, de las diez estrofas de esta composición; y, por supuesto, entre el Dios del enunciado y la instancia enunciadora del texto. Si el poema tematiza en cada estrofa un tipo de transformación, qué duda cabe que la final, aquella que es perfecta y obra de Dios y que acontece en la estrofa décima (número de los mandamientos), evoca en el nivel de sentido figurado «la transmutación del "sujeto" en "objeto poético"», por decirlo con las palabras de Sijé, transmutación que se acaba de cumplir cuando finaliza la creación del propio poema. «El silbo de las ligaduras» ${ }^{36}$, como su título parece indicar, evoca figurativamente el deseo del Yo de librarse de toda dependencia, y posee un sentido místico, pero también metapoético (alude al paso de la segunda a la tercera luna, en la terminología de Sijé). La composición está integrada por doce estrofas que forman cinco preguntas, de diferente longitud: cuatro de ellas acerca de diferentes "ligaduras" simbólicas, mien-

y profunda del clasicismo, que expresa el «dolor divino de la muerte» «gloriosamente en un silbido» (Sijé 1935: 2I).

34 «El silbo del dale // Dale al aspa, molino, / hasta nevar el trigo. // Dale a la piedra, agua, / hasta ponerla mansa. // Dale al molino, aire, / hasta lo inacabable. // Dale al aire, cabrero, / hasta que silbe tierno. // Dale al cabrero, monte, / hasta dejarle inmóvil. // Dale al monte, lucero, / hasta que se haga cielo. // Dale, Dios, a mi alma, / hasta perfeccionarla. // Dale que dale, dale / molino, piedra, aire, // cabrero, monte, astro; / dale que dale largo. // Dale que dale, Dios, / ¡ay! / hasta la perfección» (Hernández 20I0: 316-317).

$35 \mathrm{Al}$ hablar de la decadencia de la poesía con el romanticismo, Sijé establece una equiparación entre la que él considera auténtica poesía y «el ay inseparable de Dios» (Sijé 1935: 2I). La presencia de todas estas expresiones procedentes de Sijé en la obra coetánea prueban, a mi juicio, en qué alto grado Hernández, en esta época, bebe de toda la teoría poética sijeana, incluida la tridimensionalidad del poema.

36 «El silbo de las ligaduras // ¿Cuándo aceptarás, yegua, / el rigor de la rienda? // ¿Cuándo, pájaro pinto, / a picotazo limpio // romperás tiranías / de jaulas y de ligas, // que te hacen imposibles / los vuelos más insignes // y el árbol más oculto / para el amor más puro? // ¿Cuándo serás, cometa, / para función de estrella, // libre por fin del hilo / cruel de otro albedrío? // ¿Cuándo dejarás, árbol, / de sostener, buey manso, // el yugo que te imponen / climas, raíces, hombres, // para crecer atento / sólo al silbo del cielo? // ¿Cuándo, pájaro, yegua, / cuándo, cuándo, cometa; / di, cuándo, cuándo, árbol? // Cuando mi cuerpo vague / asunto ya del aire» (Hernández 2010: 318). 
tras que la quinta reúne y "liga" en sí los sujetos de las preguntas anteriores (estableciendo, por tanto, una "ligadura" nueva entre todos ellos, de naturaleza poética, formal). A las cinco preguntas, a un tiempo místicas y metapoéticas, se contesta con el pareado final: «Cuando mi cuerpo vague / asunto ya del aire». Si en un sentido místico el cuerpo asunto o asumido por el aire es una metáfora de la muerte, en un sentido metapoético se alude a la transmutación del sujeto (que traerá consigo la ruptura de las ligaduras). Nótese que esta respuesta se ubica precisamente al final del "cuerpo" del poema, inmediatamente antes del espacio en blanco final, representándose plásticamente esa asunción del "cuerpo" por parte del aire a través de la mancha negra de tinta que es el poema flotando en el espacio blanco de la caja tipográfica.

A raíz de su segundo encuentro con Neruda en Madrid, Miguel Hernández irá descubriendo que la visión de la poesía de su admirado «compañero del alma» oriolano es muy limitada, muy provinciana, y, además, ideológicamente retrógrada. Son varios los críticos -especialmente Ferris (2002) y, sobre todo, Stauder (2009) - que han detallado la evolución de la poética hernandiana en el lapso de tiempo comprendido entre Perito y El rayo: hasta finales de 1934 aún es decisiva la influencia de Sijé, pero, desde diciembre de este año y durante la primera mitad de $1935^{37}$, su acercamiento a la poética impura nerudiana se producirá muy rápidamente. En junio de I935, parece haber culminado el proceso de distanciamiento poético e ideológico de $E l$ Gallo Crisis, según confiesa en carta a Juan Guerrero Ruiz:

Tiene que perdonarme que no le enviara mi auto sacramental [...]. Ha pasado algún tiempo desde la publicación de esta obra, y ni pienso ni siento muchas cosas de las que digo allí, ni tengo nada que ver con la política católica y dañina de Cruz y Raya, y ni mucho menos con la exacerbada y triste revista de nuestro amigo Sijé.

En el último número aparecido recientemente de El Gallo Crisis sale un poema mío escrito hace seis o siete meses: todo él me suena extraño. Estoy harto y arrepentido de haber hecho cosas al servicio de Dios y de la tontería católica. Me dedico única y exclusivamente a la canción y a la vida de tierra y sangre adentro: estaba mintiendo a mi voz y a mi naturaleza terrena hasta más no poder, estaba traicionándome y suicidándome tristemente. Sé de una vez que a la canción no se le puede poner trabas de ninguna clase: no sé cómo explicar esto. [...] Me mantengo en Madrid por ahora trabajando en una enciclopedia taurina que va a editar Espasa-Calpe, dirige Ortega y Gasset y ordena J. M. de Cossío (Hernández 20IO: I535-I536).

37 Ya en enero de 1935 escribe a José Bergamín: «Ya me lo explico lo de su posición con respecto a la revista nuestra: ve en ella-¿no?- catolicismo exacerbado, intransigente, resultante de la soledad y el carácter soberbio e impetuoso de Sijé, que la escribe. Yo no le diré nunca nada porque se irritaría. Ahora quiere que demos un almanaque para marzo con los cuatro evangelios relacionados con las cuatro estaciones. [...] Estoy haciendo muchos sonetos; pastores y no» (Hernández 20I0: 1525). 
Si las «trabas» parecen aludir a la limitada visión de la poesía de Sijé, la referencia a la «sangre» ciertamente posee la misma filiación que Stauder le atribuye en el poema «Oda entre sangre y vino a Pablo Neruda», redactado en el verano de 1935: «indica ya la estrecha relación con el modelo nerudiano, así que Marie Chevallier (I977: 276), la gran especialista hernandiana, habló acertadamente de un "poema-espejo". Sangre y vino eran palabras clave en la filosofía vitalista del chileno» (Stauder 2004: 4). En enero del 35, pese a que critica a Sijé, Miguel Hernández señala estar «haciendo muchos sonetos; pastores y no» (Hernández 20IO: I525), pero ya en julio de ese año se encuentra inmerso en la poética impura nerudiana y le confiesa por carta a Josefina que «[...] mi amigo Pepito está disgustado conmigo porque le dije hace tiempo que está demasiado metido en la iglesia siempre» (Hernández 20IO: I54I). Como es sabido, la ruptura entre los dos amigos se produjo en noviembre, tras ver la luz el primer número de Caballo verde para la poesía, en el que Miguel publicaba un poema, asumiendo las propuestas de «Sobre una poesía sin pureza», el programático texto nerudiano que abría la revista (Neruda I935a: 3). Si en el número I Neruda señalaba que todo debe caber en la poesía, incluida la manida expresión «corazón mío», porque «quien huye del mal gusto cae en el hielo» (Neruda 1935a: 3), en el número 2 de noviembre del 35 insistía en que

El sitio del corazón nos pertenece. Solo solamente desde allí, con auxilio de la negra noche, del otoño desierto, salen, al golpe de la mano, los cantos del corazón. [...] la poesía mete las manos en el miedo, en las angustias, en las enfermedades del corazón. [...] El poeta vestido de luto escribe temblorosamente muy solitario (1935b: 3).

Y en el número 3, publicado en diciembre de ese mismo año, Neruda afirma en «Conducta y poesía»:

Y entonces, ¿qué queda de las pequeñas podredumbres, de las pequeñas conspiraciones del silencio, de los pequeños fríos sucios de la hostilidad? Nada, y en la casa de la poesía no permanece nada sino lo que fué escrito con sangre para ser escuchado por la sangre (1935c: 3).

Como puede comprobarse, la poética de la sangre y el corazón, abierta a todos los temas e interlocutores, se oponía radicalmente a aquella sijeana del poema cerrado como sagrario, fruto de la lógica racional, alejado de las pasiones, accesible solo a unos pocos elegidos y al servicio del catolicismo. Ese mismo mes de diciembre moría repentinamente José Marín, justo cuando Hernández estaba preparando para la imprenta El rayo que no cesa. Le dará tiempo, sin embargo, a componer e incluir en el poemario su «Elegía»: si bien había sido «proyectada como homenaje a Ramón Sijé, [las imáge- 
nes] estaban en la línea del vitalismo compartido por Hernández y Neruda» (Stauder 2004: 5). El 2 de enero de I936 Hernández publica en El Sol la entusiasta reseña a Residencia en la tierra, en la que explicita su propio gusto poético. Y para ello se sitúa en los antípodas de la poesía sijeana y de su propia poesía lunar, empezando por su rechazo a la forma como finalidad del poema, «prácticas» que solo admite «al joven que empieza y al viejo que no acaba» (Hernández 20I0: 77I). Pero, sobre todo, otorga una gran importancia al corazón (órgano que mueve la sangre) como impulsor de la creación poética y, en una alusión clara a la última frase de «Sobre una poesía sin pureza», rechaza la razón y el conceptismo, que achaca a los «oficinistas de la poesía», y cuya frialdad impide que el poema transmita emoción alguna:

Busca en otros la sujeción a la forma [...] La poesía no es cuestión de consonantes, es cuestión de corazón [... $]^{38}$ Son cosas del corazón las cosas que lo inundan, asuntos del corazón que no podrán comprender los que tienen por corazón una oficina o una maquinaria. Me irrita oír a los oficinistas de la poesía, me angustia ver este libro entre sus manos. [...] Esta es la poesía que prefiero, porque sale del corazón y entra en él directa. Odio los juegos poéticos del solo cerebro. Quiero las manifestaciones de la sangre y no las de la razón, que lo echa a perder todo con su condición de hielo pensante [...] (Hernández 2010: 770775; la cursiva es mía).

Al igual que Lorca, como vimos, Hernández se da cuenta de que la poesía ingeniosa, gongorina y pura, aquella que «acata» las leyes canónicas de la poesía, es claramente inferior a la que procede del corazón, que las supera (poesía inspirada que logra la evasión de lo imaginativo, por decirlo con la expresión lorquiana):

[...] Ante su voz desmesurada y poderosa, ¡qué ridículos encuentro el romancillo, la cosita, los cuatro versos tartamudos, verbales, vacíos, incoloros, ingeniosos; el poemilla relamido y breve, que tantos cultivan y acatan! Estoy harto de tanto arte menor y puro. Me emociona la confusión desordenada y caótica de la Biblia, donde veo espectáculos grandes, cataclismos, desventuras, mundos revueltos, y oigo alaridos y derrumbamientos de sangre. Me revienta

38 Esta postura presenta una oposición diametral a la poética sijeana de El Gallo Crisis, donde José Marín había publicado su artículo sobre el romanticismo «La decadencia de la flauta», en el que podemos leer afirmaciones como «la poesía es estilo»; o «El romanticismo, como actitud vital, está superado por el cristianismo [...] por un estilo. El estilo de pensar contra el pensamiento, en el espíritu, de amar contra el corazón, en el alma; y que en España se manifiesta, o se convierte en fruto, en la crítica más severa que se ha hecho del pensamiento desde el punto de vista del pensamiento: el conceptismo, y en la crítica más apurada del amor. [...] El estilo es la forma de eternidad sinfónica del pensamiento [...] El romanticismo ha huido del estilo, huyamos constantemente del romanticismo. El hombre de hoy debe tener su cabeza en la mano, y no meter su cabeza en el corazón [...] Golpear su cabeza con estilo» (Sijé 1935: 20-23). 
la vocecilla mínima que se extasía ante un chopo, le dispara cuatro versitos y cree que ya está todo hecho en poesía (Hernández 20I0: 775; la cursiva es mía).

Sin embargo, ni entonces ni después, ni en la poesía que escribe durante la guerra civil, ni siquiera en su Cancionero y Romancero de ausencias, Miguel Hernández renunciará a introducir esa tridimensionalidad en sus poemas. Creará un segundo nivel de sentido de carácter metaliterario a través de diversas estrategias autorreferenciales, aprendidas bajo el influjo de Marín, sí, pero que después pondrá al servicio de una poética nerudiana, laica y progresista, según podrá comprobarse en el próximo apartado. En él propondré la lectura autorreferencial implícita de cinco conocidos poemas hernandianos: no insistiré, por consiguiente, en los diferentes aspectos y variantes de su interpretación literal, ya extensamente examinados por la crítica, sin ir más lejos en este mismo número de Versants (véanse al respecto los artículos de Urrutia, Ferris, Ruiz Pérez, Scarano o Rovira).

\section{Autorreflexión e iconicidad en cinco poemas emblemáticos}

\section{I. «Un carnívoro cuchillo» 39}

El poema liminar de El rayo que no cesa, al igual que el de Perito en lunas, instaura un segundo nivel de sentido que hace referencia a la transmutación del sujeto en objeto poético: esta comienza con el acto de escritura, de ahí que el lugar preferencial para evocarla implícitamente sea el inicio del libro, haciéndose coincidir enunciado y enunciación. Si la elección de la forma métrica de los tres «Silbos» parecía haber estado determinada por la función plástica que cumplía al representar visualmente un silbido, resulta plausible que igual motivación llevase a nuestro autor a emplear la cuarteta octosilábica en el poema inaugural de su segundo libro: no creo, pues, casual que la única vez que se utilizan los versos de arte menor en este poemario coincida con la tematización del cuchillo o «rayo de metal» (o «grito» puntiagudo de la primera luna sijeana), es decir, ese impulso creador constante

39 «Un carnívoro cuchillo / de ala dulce y homicida / sostiene un vuelo y un brillo / alrededor de mi vida. // Rayo de metal crispado / fulgentemente caído / picotea mi costado / y hace en él un triste nido. // Mi sien, florido balcón / de mis edades tempranas, / negra está, y mi corazón, / mi corazón con canas. // Tal es la mala virtud / del rayo que me rodea, / que voy a mi juventud / como la luna a mi aldea. // Recojo con las pestañas / sal del alma y sal del ojo / y flores de telarañas / de mis tristezas recojo. // ¿A dónde iré que no vaya / mi perdición a buscar? / Tu destino es de la playa / y mi vocación del mar. // Descansar de esta labor / de huracán, amor o infierno / no es posible, y el dolor / me hará a mi pesar eterno. // Pero al fin podré vencerte, / ave y rayo secular, / corazón, que de la muerte / nadie ha de hacerme dudar. // Sigue, pues, sigue cuchillo, / volando, hiriendo. Algún día / se pondrá el tiempo amarillo / sobre mi fotografía» (Hernández 1976: 145-6). 
que atormentaba a Hernández. Porque gracias a la forma métrica, el poema se visualiza como una sombra negra y estrecha que atraviesa longitudinalmente la caja tipográfica y queda suspendida en el blanco de la hoja; esto es, emula ópticamente ese «cuchillo» que vuela sostenidamente «alrededor de mi vida», estableciendo una equivalencia entre la figura tematizada y el propio texto ${ }^{40}$. Buena parte de las imágenes con que es descrito el «cuchillo» se explican por su sentido figurado, de carácter metaliterario: ese impulso poético constante -cuchillo, rayo, pena: siempre se trata de un elemento picudo, brillante y/o amarillo- obra la transmutación del sujeto en objeto, lo mata simbólicamente. Por eso es «carnívoro» y su ala (u hoja), «homicida» ${ }^{41}$, aunque «dulce» (pues es de naturaleza poética). En la segunda estrofa, el cuchillo es «rayo de metal» (y no podemos ignorar que es el primer poema de un libro titulado El rayo que no cesa): se come la carne del Yo y su punta queda metaforizada en el pico de un «ave» (estr. 8) que «picotea» (estr. 2) el costado del Yo. Al añadir el sema 'pico' al de 'vuelo', se actualiza otra de las funciones del pico de las aves: el canto (poético, se sobreentiende). Tanto más cuanto que se ha instalado para reproducirse y perpetuarse en el Yo, al hacer un «triste nido» en su costado. Se produce, además, aquí una equiparación implícita entre la pasión de Cristo y la del sujeto poético: entre la lanzada del guardián romano que contribuye a su muerte y transformación final en ser eterno, y el picoteo de este cuchillo, instalado en el costado del Yo, causándole un «dolor» que le «hará a mi pesar eterno» ${ }^{42}$. Pero es que, además, una lectura tridimensional o sijeana del poema decodificaría ese «picoteo» en «mi costado»-una acción repetitiva con el «pico», metonimia del canto- como la rima consonante, cíclica, ubicada en el «costado» derecho de la estrofa. De esta forma, quedan homologados el Yo y el propio poema, que, a su vez, debido a la forma métrica, ya había sido identificado con el rayo/cuchillo. Un rayo que procede del propio Yo -como se afirma en el segundo texto de este poemario-y se dirige contra él (para transmutarlo en poema):

40 El poema, al ser el primero, está ubicado en la parte más externa del conjunto poemático, no en su núcleo, de ahí que el vuelo sea alrededor «de mi vida», pues su acción homicida ha empezado apenas.

4I «Homicida», puesto que ha de morir el sujeto, según Sijé, para llegar al alma y no a la nada: «la poesía es un puente entre dos objetos [...] entre la realidad y el poema. Si la poesía puede cerrarse sobre sí misma -si puede concebirse una poesía pura- es por la conversión de la corriente en cristal, de la poesía en objeto. Ahora bien, cuando el alma pasa por la poesía la transforma en objeto: en soneto. [...] por el camino del sujeto [...] se llega a la nada: y por el camino del objeto, al alma» (Sijé 1935: 46).

42 Se trata, pues, de una postfiguración -empleo el término con el sentido que le otorga Deyermond (1985: 245-367) - que homologa el sacrificio de Cristo con el del Sujeto: ambos conllevan la muerte y la posterior entrada en una vida eterna, la del paraíso para el Hijo y la del arte para el Yo poético. 
[...] este rayo que me habita

el corazón [...]

[...] de mí mismo tomó su procedencia

y ejercita en mí mismo sus furores.

Esta obstinada piedra de mí brota

y sobre mí dirige la insistencia

de sus lluviosos rayos destructores (Hernández I976: I47).

Los efectos del cuchillo se describen en la estr. 3. En primer lugar, tizna de negro la sien (pues es rayo), metonimia de la razón, del «hielo pensante» (Hernández 20I0: 775) con el que Hernández componía la poesía conceptista de su juventud: por eso, el rayo fulmina ese «florido balcón / de mis edades tempranas» (la cursiva es mía). En segundo lugar, envejece o hace madurar al «corazón», metonimia de las pasiones, si bien aquí, además, posee el sentido que ya vimos le otorgaba Neruda, y que Hernández se apropió y convirtió en emblema de su poesía (de ahí, en primer lugar, que se subraye con una anadiplosis y que, en segundo lugar, en la estr. 8 se llame al cuchillo «ave», «rayo secular»-esto es, no sacro-y también «corazón», estableciendo una equivalencia entre los tres). Porque el rayo posee la «mala virtud» ${ }^{43}$ de distanciar al Yo de su juventud (de su edad efímera), de hacer que esta no forme parte de su esencia, sino que él vaya a ella cíclicamente, «como la luna a mi aldea». En este verso el sentido metaliterario derivado de su iconicidad temporal se impone claramente: la «juventud» del poema, su inicio, es revisitado cíclicamente por el Yo (en cada nueva lectura). Mediante la misma estrategia autorreflexiva, el Yo asegura su victoria sobre el rayo y la afirma, desafiante, justo en la penúltima y última cuartetas, llegando al final, a la «muerte» del poema, un momento que indudablemente ha de venir tanto en el hombre como en cualquier composición: una vez terminado el poema, se habrá operado la transmutación del sujeto en objeto, el rayo habrá sido vencido y cesará, y el Yo-poema entrará en el tiempo circular del arte (por eso el rayo le «hará [...] eterno»). La cuarteta 5 también pone en escena varios recursos icónicos que generan una coincidencia entre enunciado y enunciación. En primer lugar, la ubicación de la forma verbal recojo en el inicio y también en el final de estrofa -como cercando todo lo que queda entre medias, esa metafórica cosecha del Yo-, escenifica plásticamente el acto de recoger o «juntar cosas separadas o dispersas» (DRAE, s. recoger). En segundo lugar, el Yo hace esta cosecha «con las pestañas», que, en una lectura tridimensional, figurativizan los propios versos -también de color negro y longitudinales- en

43 Adviértase cómo el efecto del rayo-cuchillo se describe con un oxímoron, figura retórica que a menudo emblematiza la poesía por designar lo inefable. 
los que queda encerrada la esencia poética, a saber: la «sal» (con el sentido que ya vimos en «Mi concepto de poema»), sea del alma, sea de cuanto percibe el ojo, y también quedan allí las «flores» hechas con las «telarañas» de «mis tristezas» (es decir, el material con el que se hacen las «flores» son las telarañas que les han salido a las penas de lo viejas que son: la distancia emocional y temporal es, por tanto, grande). En la estr. 6 el avance del propio poema es la «perdición» del Yo, pues, haga lo que haga, llegará al final (de la vida, del texto), dado que el destino del rayo es acabar siendo poema o playa (esto es, límite del mar, límite de la vocación cíclica, eterna, del Yo). Este avance constante e imparable del propio texto es la causa de que el Yo, en la estr. 7, afirme que no puede descansar -si bien ese dolor le «hará [...] eterno»- en el camino hacia su plena transformación en objeto poético: esa autorrepresentación, esa fotografía de la estr. 9. En ella, el tiempo adquirirá la calidad amarilla del rayo-cuchillo, ahora poetizado y, por consiguiente, cristalizado en poema, insertado en un tiempo cíclico, renovable con cada nueva lectura, durante la cual el cuchillo seguirá «volando, hiriendo».

\section{2. «Umbrío por la pena» 44}

En este soneto, el sexto de El rayo, el influjo de la poética sijeana es muy intenso, tanto que algunos de sus versos - por ejemplo, el 3 y el 4 - no resultan, a mi parecer, comprensibles sino desde una lectura figurada de carácter metapoético. O, lo que es lo mismo, en ellos el nivel de sentido implícito se impone sobre aquel explícito ${ }^{45}$, que queda desplazado.

El embrague textual más evidente figura en el v. I4, donde se hace coincidir el final del poema con la muerte del Yo («iCuánto penar para morirse uno!», 1976: 15I). Esta equivalencia entre lo enunciado y su enunciación establece, por un lado, una identidad entre el poema y ese Yo-«uno»; y, por otro, entre el «penar» del Yo y el propio proceso de escritura. El final de esta composición, pues, obliga al lector competente a volver sobre sus pasos y releerla desde una perspectiva autorreferencial en la que cuanto el Yo predica de sí se predica asimismo del poema.

Ya vimos que el efecto de la acción del rayo/cuchillo es esa mancha de color negro, pues el impulso poético -el rayo o, aquí, la pena-, cuando «es-

44 «Umbrío por la pena, casi bruno, / porque la pena tizna cuando estalla, / donde yo no me hallo no se halla / hombre más apenado que ninguno. // Sobre la pena duermo solo y uno / pena es mi paz y pena mi batalla, / perro que ni me deja ni se calla, / siempre a su dueño fiel, pero importuno. // Cardos y penas llevo por corona, / cardos y penas siembran sus leopardos / y no me dejan bueno hueso alguno. // No podrá con la pena mi persona / rodeada de penas y de cardos: / ¡cuánto penar para morirse uno!» (Hernández 1976: 15I).

45 Algo, por otro lado, muy frecuente en la poesía conceptista, especialmente en las agudezas complejas, como tuve ocasión de estudiar y demostrar para la Poesía religiosa cómico-festiva del Bajo Barroco (López Guil 201I). 
talla» ${ }^{46}$, genera la transmutación del sujeto en poema, esto es, lo tizna (lo transforma en tinta negra sobre papel blanco): precisamente la alusión a esa conversión del Yo en poema es, a mi juicio, la única posible interpretación de los versos 3 y 4 («donde yo no me hallo» -es decir, en el poema- «no se halla hombre más apenado que ninguno», la cursiva es mía), que, en la habitual lectura literal de carácter amoroso, me resultan más enigmáticos.

Ahora bien, para su cabal comprensión, esta «pena» o impulso poético debe leerse a la luz de las teorías que Sijé expone en «La decadencia de la flauta» (I935: 20-25), donde frente a la espontaneidad superficial del romanticismo, que solo se queda en la «llaga», el amigo de Hernández propone un trabajo de estilo -cerebral, conceptista- con el que se consigue llegar, a través del dolor, al clasicismo ${ }^{47}$. Según Sijé, se trata este de un estilo que profundiza hasta el «hueso» del pensamiento, que trasciende los siglos y, por tanto, salva al alma del paso del tiempo. El cardo «es rey, esclavo de su corona»: representa el estilo sacro -los grandes estilos, dice, «son las grandes espinas»-, ascético, superior al romanticismo y al clasicismo, pues «separa el trino del mensaje, al Bautista del Cristo» y Sijé lo encarna en la «limpieza escultórica de la palabra» de San Juan ${ }^{48}$. Resumiendo, la pena, el

46 Nótese que la definición de «estallar» (Moliner, s. estallar: «Principiar bruscamente una cosa; como una guerra, una tormenta o un incendio») comporta los semas 'tormenta' y 'fuego'. 47 «[...] la naturaleza dolorosa del pensamiento, que busca en el arte la manera de inmortalizar su angustia religiosa y humana: la manera de pintar el eterno barroco: de coordinar el laberinto de su destino con la selva de Dios» (Sijé 1935: 30).

48 «Porque el romanticismo no ha llegado a los puros huesos, a la desnudez esencial y existencial del pensamiento: está en las puras llagas [...] se nace romántico, prehistóricamente cristiano; pero uno, con el trabajo diario de estilo, se hace clásico, viejo: uno se salva. [...] El romanticismo cambió la musicalidad por el grito [...]. El romanticismo ha huido del estilo, huyamos constantemente del romanticismo. El hombre de hoy debe tener su cabeza en la mano, no meter su cabeza en el corazón [...] Coger la cabeza, y lanzarla-en in-humano impulso- contra los problemas del tiempo. Golpear su cabeza con estilo. Contra la viviente tierra española. [...] Vuelta a la realidad, a las cosas, a los casos, a las causas: al encuentro del cardo. Puede construirse sobre el cardo todo un curso de vida espiritual del hombre: de depuración ascética del pensamiento: de elevación de la doctrina al martirio. El cardo es un estilo: el estilo de ser cardo. [...] Porque los grandes estilos son las grandes espinas. [...] En el cardo percibimos el ens, creamos la realidad. Realidad es la proyección imaginativa de una cosa: del cardo. Frente a una metafísica del cardo no hay romanticismo que valga. // -El romanticismo a cardo. Ay, cardo! Ámame con espina, Déjame dolor con el puro quedatiempo de tu sonido. Ay, cardo, paisaje y celda! // La realidad está elevada a realeza. El cardo es rey, esclavo de su corona. En el cardo no hay posibilidad de edad de oro, de edad de trino. Arrojemos la flauta contra el cardo: es el símbolo de la naturaleza caída: de la naturaleza continuamente redimiéndose. -Te has hecho sangre con el cardo, hermana mía: el cardo crea, el ser crea. El cardo, en definitiva, separa el trino del mensaje, al Bautista del Cristo. // En la soledad del cardo he intentado formar el tumulto, la popularidad, la anécdota, el rebaño y el grito:-Juanico! El eco, el drama de Dios, el cardo de Dios que mortifica la montaña, responde en la limpieza escultórica de la palabra, en la belleza de la tradición verbal de la santidad: Juan. Estamos en el reino de las palabras divinas: "In principio erat verbum, et verbum erat apud Deum, et Deus erat verbum" (Juan, c. I, v. I)» (Sijé 1935: 24-25). 
dolor, forman parte del proceso de lucha por conseguir un estilo que llegue al «hueso» del pensamiento y no se detenga en la llaga, en lo superficial. Dicho proceso, naturalmente, se realiza en soledad (v. 5) ${ }^{49}$ y Hernández, en este poema, lo identifica con su «rayo», esa pena que, cuando da resultados es «paz» momentánea, y el resto del tiempo, «batalla»; una pena que lo atormenta con la constancia del perro del hortelano (vv. 6-8) y que, como él, es «fiel», pero «importuno».

La versión del primer terceto en $E l$ silbo, al homologar cardos y penas y convertirlos en agentes de la acción, era más explícita y acentuaba los conceptos sijeanos de este poema: «Cardos, penas, me ponen su corona / cardos, penas me azuzan sus leopardos». En esta primitiva versión los cardos y penas (que la enumeración convierte en sinónimos) transferían su corona real al Yo-poema (confiriéndole un estilo clásico) y le azuzaban sus leopardos hasta destrozarle todos los huesos (es decir, llegaban hasta lo profundo del pensamiento, no se quedaban en la llaga, como los autores románticos, según Sijé). Los «leopardos», sin duda, remiten a esas «fieras» que, en el soneto 2, el rayo hace habitar en el «corazón» del $\mathrm{Yo}^{50}$ y que, evidentemente, por orden de los cardos y las penas causan en el Yo ese «dolor» que José Marín creía necesario para llegar a la consecución de un estilo clásico: aquel que nuestro poeta identificaba con la tortura de su constante impulso creador. En la versión de El rayo, sin embargo, es el propio Yo quien porta una corona de cardos y penas: a través de esta postfiguración, se homologan la pasión de Cristo y la del Yo en su transmutación, en tanto que paso previo al sacrificio final que, tras su muerte, llevará a ambos a la vida eterna. En el segundo verso los «leopardos» ${ }^{11}$ ya no se «azuzan», sino que se «siembran», de modo que obligan a leer sin connotaciones crueles, como algo positivo, el hecho de que no dejen sin romper hueso alguno al Yo -son «homicidas», como el rayo»-, ya que da lugar al fruto de esta dolorosa cosecha, que es el propio poema ${ }^{52}$.

49 Si en la versión primitiva de El silbo («Pena con pena y pena desayuno») el «desayuno» de la pena, en tanto que comida inicial del día, se hacía coincidir con el inicio de la segunda estrofa (apenas recién creado el Yo-poema), en la versión definitiva el embrague ya no es temporal sino espacial: la forma verbal «duermo» (y con ella el Yo) se ubica en medio del primer verso de la segunda estrofa, en el verso que descansa o «duerme» sobre el resto de la estrofa (como el Yo sobre la pena).

50 «¿No cesará este rayo que me habita / el corazón de exasperadas fieras [...]» (Hernández 1976: 147).

5I La elección de los «leopardos» para representar a estas fieras naturalmente está determinada por la rima con «cardos", pero no descarto tampoco que haya estado guiada por las manchas negras de su piel que podrían evocar, visualmente, el perfil de las letras sobre la caja tipográfica (amén de tener el color amarillo del rayo y ser carnívoros, como el cuchillo).

52 Adviértase además que sembrar conlleva la entrada en el tiempo cíclico de la agricultura, a menudo comparado por Hernández en sus poemas «hortelanos» con el propio ciclo poético (es, de hecho, uno de sus embragues textuales preferidos en El Rayo). 
En el segundo terceto se declara la victoria de la pena sobre el sujeto poético, pues ya casi se ha conseguido la transmutación de «mi persona» en «objeto poético», estando como está «rodeada de penas y de cardos» ${ }^{53}$. La exclamación final que cierra el soneto y que actúa de embrague entre su sentido literal a moroso y este figurado de carácter metaliterario que he intentado mostrar, enfatiza el dolor que causa tanto «penar», esto es, el proceso de escritura de un soneto de factura «clásica» (en el sentido que Sijé otorga a este término) que ha de matar al sujeto para que perviva el «hijo", que es como llama Sijé (1935) en repetidas ocasiones al poema clásico, estableciendo un paralelismo con Cristo (tal y como hace aquí Hernández).

\section{3. «Como el toro he nacido para el luto» ${ }^{54}$}

El soneto 23 de El rayo es, quizá, el más famoso de cuantos poemas tauromáquicos escribió Hernández. Si, como dijimos, el efecto del rayo es el tizne, la negra figura del toro se prestaba muy bien para encarnar ese poema fruto de la pena y de la transmutación del sujeto: de ahí que el Yo-poema se identifique con el astado, pues ambos han «nacido para el luto / y el dolor». Adviértase que se produce aquí un embrague textual, al hacerse coincidir ese «he nacido» con el inicio o nacimiento del poema: si el Yo que comienza con el texto cuando acabe ha de morir, ha de sacrificarse, también el toro por fuerza terminará muriendo en la corrida. De este modo, la existencia de ambos se presenta sujeta a una temporalidad semejante: efímera para el sujeto/toro individual, pero cíclica con cada nueva lectura/corrida. La metáfora de la rima como marca de «un hierro infernal» (cuchillo o rayo) en el costado - que ya vimos en el poema liminar de El rayo- se repite aquí. Además, se introduce una nueva figura: la del sexo masculino erecto, símbolo del deseo que atormenta al Yo en el nivel literal de sentido, pero emblema del verso -ya que es "marca» del Yo, como la rima- en el sentido figurado (por su dimensión longitudinal y ser un «fruto»).

En el segundo cuarteto el sentido literal predomina sobre el figurado, si bien hay una clara alusión a la poética nerudiana en esa «desmesura» del «corazón» que, como acertadamente interpretó Balcells (I99I: 8I), también remite a

53 Y está literalmente «rodeada» al ocurrir «cardos y penas» al inicio del primer terceto y cerrarse el penúltimo verso con «penas y cardos», con esa inversión de ambos términos que, al generar simetría, acentúa su carácter envolvente.

54 «Como el toro he nacido para el luto / y el dolor, como el toro estoy marcado / por un hierro infernal en el costado / y por varón en la ingle con un fruto. // Como el toro lo encuentra diminuto / todo mi corazón desmesurado, / y del rostro del beso enamorado, / como el toro a tu amor se lo disputo. // Como el toro me crezco en el castigo, / la lengua en corazón tengo bañada / y llevo al cuello un vendaval sonoro. // Como el toro te sigo y te persigo, / y dejas mi deseo en una espada, / como el toro burlado, como el toro» (Hernández 1976: I70). 
La tiranía del cauce formal empleado, mayormente el soneto. Esta tensión puede ilustrarse con versos del poema 23: «Como el toro lo encuentra diminuto / todo mi corazón desmesurado». En estas líneas se aprecia cómo la tensión viene dada por una desmesura del sentimiento, desmesura que tiene algo de hiperbólico, desde luego, pero no deja de ser un sentir desmesurado que debe reducirse titánicamente para caber en el ámbito estrecho, diminuto, carcelario, del soneto.

La «desmesura» o falta de medida se plasma autorreferencialmente en el encabalgamiento suave que, por medio del hipérbaton, prolonga la oración hasta el sexto verso, situando «diminuto» como palabra rima a final del quinto verso ( $\mathrm{y}$, por tanto, connotando tal espacio textual: el verso es un molde diminuto, pues no logra contener toda la oración). En los vv. 7 y 8 predomina el sentido amoroso literal, si bien con una metafórica referencia al tercio de varas, donde el picador tantea al toro que lo ataca de cara. De hecho, el carácter tridimensional del soneto se aprovecha para tematizar con él los tres tercios en los que se divide la corrida. En el espacio-tiempo de los dos cuartetos queda representado el tercio de varas (aquel en el que el picador tantea y conoce al toro: por tal motivo se procede aquí a la descripción del astado). El primer terceto se asocia al tercio de banderillas (a las que se alude, metafóricamente, mediante el «vendaval sonoro»), el momento en el que el toro es más castigado para que recupere su bravura después de la labor del picador. En el postrer terceto se tematiza el último tercio, el de muerte, donde el torero se luce con la faena de muleta (que el toro sigue y persigue), para acabar matándolo con la espada (burlando, «esquivando sus acometidas [...] hasta darle muerte», DRAE, s. correr).

El primer terceto se abre con un embrague, pues, efectivamente, a medida que el castigo/pena (de banderillas/de escribir) aumenta, el toro se vuelve más bravo y el texto «crece» literalmente en extensión. En el v. Io predomina explícitamente el aspecto metaliterario, ya que se reivindica la poética nerudiana del «corazón» mediante una imagen muy similar a la que cierra el poema $17^{55}$ :

[...] tú, mi sangre astada, que el cotidiano cáliz de la muerte, edificado con un turbio acero,

vierte sobre mi lengua un gusto a espada

diluida en un vino espeso y fuerte

desde mi corazón donde me muero (Hernández 1976: I64).

55 Adviértase cómo aquí emplea otra vez Hernández la estrategia autorreferencial de hacer coincidir la muerte del Yo con la muerte/final del poema. 
El último terceto tematiza, en su sentido literal, la semejanza entre la muerte del toro, burlado, que tiene lugar «en una espada» y el insatisfecho deseo del Yo (que la amada «deja» en una espada, burlado, en una referencia metafórica a la erección; véanse Martín 20I0: 362 y Balcells 20I5: 99-IO0). En cambio, en su sentido implícito, el deseo amoroso figurativiza el impulso creador del Yo, que queda en la «espada», esto es, en el propio verso donde muere el Yo, burlado y llevado al sacrificio como el toro (recuérdese que Sijé, en su interpretación tridimensional de soneto, asociaba sus catorce versos a «catorce puñaladas en la soberbia del poeta», I935: 46-47).

\section{4. «El herido (II)» $\mathrm{y}$ «Llegó con tres heridas»}

Como se ha dicho antes, Miguel Hernández evolucionará en su poética abandonando los presupuestos sijeanos, pero no las estrategias autorreferenciales con él aprendidas. Sirvan de botón de muestra «El herido (II)» de El hombre acecha (1938-1939) y «Llegó con tres heridas» del Cancionero y romancero de ausencias (I942). En ambos poemas se emplea, respectivamente, la ausencia de un hemistiquio y el verso de pie quebrado de forma intencionada para representar plásticamente -con respecto a los versos completos o sanos- «la carne talada» (v. I6) y las «tres heridas» (pues no es casual que este texto tenga precisamente tres pies quebrados, uno por herida).

«El herido (II)» ${ }^{56}$ fue escrito para ser colgado en «el muro de un hospital de sangre», esto es, donde se supone realizaban las primeras curas a los heridos en el frente. De ahí que, en su sentido literal, se insista en las causas por las que el Yo se ha entregado a la lucha y está herido: la libertad política.

La forma del poema genera un embrague textual entre el tema del enunciado -un Yo herido- y cómo se expresa, a saber: mediante una cuarteta alejandrina en cuyo último verso está amputado el segundo hemistiquio, volviendo autorreferencial cuanto el Yo afirma de sí (el propio poema es, pues, «El herido» del título, y la voz que dice Yo puede interpretarse también como la del texto hablando de sí mismo). La repetición anafórica del sintagma «Para la libertad» al inicio de las tres primeras cuartetas las unifica en una misma secuencia discursiva. En ella la estrofa inicial presenta en su primer verso las acciones que el Yo tematizará en las cuartetas que siguen:

56 «Para la libertad sangro, lucho, pervivo. / Para la libertad, mis ojos y mis manos, / como un árbol carnal, generoso y cautivo, / doy a los cirujanos. // Para la libertad siento más corazones / que arenas en mi pecho: dan espuma mis venas, / y entro en los hospitales, y entro en los algodones / como en las azucenas. // Para la libertad me desprendo a balazos / de los que han revolcado su estatua por el lodo. / Y me desprendo a golpes de mis pies, de mis brazos, / de mi casa, de todo. // Porque donde unas cuencas vacías amanezcan, / ella pondrá dos piedras de futura mirada, / y hará que nuevos brazos y nuevas piernas crezcan / en la carne talada. // Retoñarán aladas de savia sin otoño / reliquias de mi cuerpo que pierdo a cada herida. / Porque soy como el árbol talado, que retoño: / porque aún tengo la vida» (Hernández 2010: 573-574). 
«sangra» en la $2^{\mathrm{a}}$, «lucha» en la $3^{\mathrm{a}} \mathrm{y}$ "pervive» en la $4^{\mathrm{a}}$ y la $5^{\mathrm{a}}$ (en tiempo verbal futuro). Nótese que en el v. 2 el Yo entrega a los «cirujanos» para que le amputen aquellos órganos y miembros que se ven implicados en la creación poética, a la cual hacen referencia de forma metonímica: «ojos» (mirada) y «manos» (escritura). Adviértase, asimismo, cómo, de forma icónica, se ubica la palabra «mano» que designa la extremidad del cuerpo humano en el final de verso (que después será amputado). En el sentido literal el texto establece una equivalencia entre el cuerpo del Yo y un árbol; entre la entrega voluntaria que hace el sujeto herido para que le sean amputados manos y ojos, y el árbol -cautivo en sus raíces, en su vida terrena- que se ofrece a ser talado: dicha equiparación homologa en su función a los cirujanos con los leñadores. En un sentido figurado, los «cirujanos» personificarían, en ese sometimiento del Yo, el propio molde métrico que recorta el impulso creador de manera que la transmutación se cumpla y el Yo muera, pero consiga pervivir en el objeto poético57.

Ya hemos visto en poéticas y poemas anteriores el sentido nerudiano de los «corazones» que el Yo siente en «mi pecho» -voz ubicada icónicamente en el centro del v. $6-$ y aquel de la «espuma» ${ }^{58}$ que «mis venas» ${ }^{59}$ «dan»: la transmutación se está operando y la sangre es ya una espuma poética, que entra en hospitales y algodones (tema literal del poema) con la misma facilidad que lo haría en azucenas ${ }^{60}$ (cuyo color blanco, como el del algodón, remite al de la página donde el poema está «cristalizando», está entrando).

Si en los dos primeros versos de la estrofa 3 prevalece el sentido literal $^{6 \mathrm{r}}$, en los dos últimos existe un embrague textual que destaca su sentido metaliterario, ya que los «pies» y, sobre todo, los «brazos» del verso II -plásticamente representados al final de este segundo hemistiquio-desaparecen en el v. I2 (donde solo hay un hemistiquio heptasilábico). De este modo, el poe-

57 La humildad del poeta, en la teoría de Sijé, se muestra en el sometimiento a la forma: «Porque la conversión de la poesía en objeto consiste en encerrar en el sagrario del soneto -o en otro tipo poético tridimensional [...]- el tiempo y el espacio. [...] Porque la creación toca al sufrimiento y al dolor más abstracto y es hija humilde de ellos. Catorce puñaladas en la soberbia del poeta es el soneto. [...] El soneto es, pues, la demostración de la humildad creadora del poeta. Cuando el poeta dice soneto, el aire se estremece, y nos devuelve la palabra, ya con una finalidad poética y metafísica: Me someto» (Sijé 1935: 46-47).

58 Recuérdese su sentido metaliterario en «Fórmulas», n. 30.

59 Metáfora de los propios versos por los que circula la espuma/sangre.

60 La mención de las azucenas constituye una referencia literal a la poética impura nerudiana expresada en el primer número de Caballo verde para la poesía (1935:3): «Así sea la poesía que buscamos, gastada como por un ácido por los deberes de la mano, penetrada por el sudor y el humo, oliente a orina y a azucena, salpicada por las diversas profesiones que se ejercen dentro y fuera de la ley». Hernández altera el binomio nerudiano insertando los hospitales y los algodones en lugar de la orina, pero manteniendo la referencia a la azucena del original, altamente metapoético donde «ley» aludía tanto a la legislación estatal como al canon poético. 6I Aunque, por supuesto, también podrían aludir a la superación de la poética neocatólica y los balazos serían simbólicos. 
ma cumple en el v. I2 -métrica y visualmente- la palabra del Yo, aquello que el sujeto poético acaba de afirmar en el v. II, esto es, que se va a desprender de «pies» y «brazos».

Las dos últimas cuartetas -en las que se tematiza la pervivencia del Yoexplican el porqué del sacrificio del sujeto poético en aras de la libertad, pues ella, esta libertad/poesía, restituirá lo carnal efímero con elementos sustitutivos ajenos al tiempo lineal. Las «cuencas vacías» de los ojos, una vez transmutado el sujeto en poema, serán "piedras» de «futura mirada». Y adviértase cómo en los vv. I5 y i6 hay un nuevo embrague en el que se invierte el proceso de amputación representado en los vv. II y I2: el retoñar de los miembros cortados se tematiza en el segundo hemistiquio del v. I5 («y nuevas piernas crezcan»), que supone un crecimiento en extensión y un contraste con el hemistiquio único del v. I6, aquel que designa «la carne talada». Y en la última estrofa se vaticina que aquello que emana cada herida del sujeto (la sangre, convertida aquí en «reliquias» o vestigios) volverá a retoñar con «savia sin otoño», es decir, con savia ajena al ciclo estacional y, por tanto, eterna (pues el objeto poemático está adscrito al tiempo circular del arte). De aquí que las reliquias retoñen «aladas» (sin las raíces del árbol «cautivo» del inicio), es decir, dotadas de la posibilidad de vuelo y, por tanto, de acceso al espacio de la trascendencia. En los dos versos finales se produce un último embrague textual: a diferencia de lo que ocurría en el v. I6, donde tras «talada» solo había un punto, en el v. I9 el crecimiento del «árbol talado» se figurativiza mediante la prolongación en el segundo hemistiquio del sintagma que expresa ese renacer («que retoño»), haciéndose coincidir la duración de «la vida» del Yo con el espacio textual del poema. De este modo, la ciclicidad de la carne retoñada se autorrepresenta en la ciclicidad de la comunicación poética: el herido retoña y «aún tiene la vida» con cada nueva lectura del poema.

En «Llegó con tres heridas» (Hernández 20I0: 600), la forma métrica, con su distribución paralelística, sostiene la expresión de la supremacía del amor sobre vida y muerte de forma visual. Los tres pies quebrados en las tres estrofas enumeran las tres heridas (quedando asimilados a ellas, como dijimos más arriba): en cada cuarteta se destaca una -la última- sobre las demás, mediante el artificio de la rima, y se liga a un tiempo verbal diferente. En la primera estrofa el tiempo verbal es perfectivo y la palabra «vida» es la que la rima subraya, asociándola con las «heridas»: de este modo, la «vida» queda impregnada del carácter terminativo del tiempo verbal y del sema 'destrucción'/‘daño' inherente a las tres «heridas». La llegada de un sujeto en tercera persona se hace coincidir con el inicio del poema, estableciéndose así una equivalencia implícita entre el comienzo de la enunciación y el carácter incoativo de la acción terminada que se tematiza, pues «llegar» es empezar a «estar en cierto sitio al que se va desde otro» (Moliner, s. llegar). 
De hecho, en una redacción anterior del poema figuraba «Nació» en vez de «llegó», de modo que la coincidencia entre enunciado y enunciación era originariamente más explícita (Hernández 1992: I083). En la segunda cuarteta el presente atemporal queda asociado por la rima a la palabra «muerte» y se emplea para describir el desplazamiento de una tercera persona -la de la estrofa I, a juzgar por las heridas- hacia un espacio próximo al Yo, puesto que «viene». En esta cuarteta la vida ha retrocedido desde el lugar más destacado que tenía en la estrofa I (palabra-rima) hasta el inicio de la enumeración. Por el contrario, la muerte y el amor han avanzado un 'puesto', ya que el amor ocupa el segundo lugar en la enumeración y la muerte es ahora la palabra-rima:

\author{
Llegó con tres heridas: \\ la del amor, \\ la de la muerte, \\ la de la vida. \\ Con tres heridas viene: \\ la de la vida, \\ la del amor, \\ la de la muerte. \\ Con tres heridas yo: \\ la de la vida, \\ la de la muerte, \\ la del amor (Hernández 20I0: 60o; la cursiva es mía).
}

La tercera estrofa se diferencia de las anteriores porque en ella desaparece toda forma verbal y temporal, y el Yo habla en primera persona, quedando asociado a la atemporalidad y a la palabra-rima «amor». Una voz esta -«amor»- que desde el inicio ha ido ganando posiciones hasta ocupar el lugar más destacado de la estrofa final y del poema. El texto, pues, se esfuerza en presentarla visualmente como la única «herida» dinámica, capaz de superar no solo a la «vida», sino también a la propia «muerte» ${ }^{62}$. Por eso el Yo, al final de su transmutación, cuando ya acaba el poema, se asocia a ella a través de la rima: Yo-poema y amor, ajenos a la linealidad de la vida efímera, acaban siendo equivalentes ${ }^{63}$.

62 Véanse, por ejemplo, al respecto las interpretaciones de Cano Ballesta (1971: 70) o de Díez de Revenga (2018: 97-IO2).

63 Una equivalencia que Hernández hacía explícitamente en la carta a Luis Almarcha citada en la n. 5 . 


\section{Conclusiones}

Miguel Hernández aprendió junto a Sijé toda una serie de estrategias textuales que nunca dejó de emplear en sus poemas para establecer en ellos un segundo nivel de sentido de carácter autorreferencial. Aunque su poética fue cambiando y variaron también los temas que trató en el sentido literal de sus composiciones -amor, justicia social, ausencia-, el poeta oriolano siguió sirviéndose de la concepción «tridimensional» del poema para establecer equivalencias icónicas de muy diferentes tipos: las más comunes son las que generan paralelismos entre las dimensiones espacio-temporales tematizadas en el enunciado y aquellas de la enunciación, o entre una figura (silbido, cuchillo, herida) del enunciado y la que forma el molde métrico elegido sobre el espacio en blanco de la caja tipográfica. El segundo nivel de sentido a menudo alude a la transmutación del sujeto en objeto poético, pero también aborda otros temas que le inquietaban, como la constancia del impulso creador, que sentía como tortura, o la propia naturaleza de la poesía.

A la luz de los textos teóricos de Sijé, de las poéticas hernandianas, así como de los poemas aquí examinados, no parece desafortunado apuntar la necesidad de una relectura de la obra hernandiana que tenga en cuenta esta perspectiva. De ese modo, las múltiples y sagaces lecturas que ya existen del sentido literal de los poemas se verían enriquecidas con esta dimensión metapoética, en cuya construcción textual Miguel Hernández puso tanto empeño.

\section{Bibliografía}

Abril, Juan Carlos, «Notas sobre la vida y la obra de Miguel Hernández», en Para la libertad. Estudios sobre Miguel Hernández, eds. Juan Carlos Abril y Luis García Montero, Jaén, Diputación de Jaén, 2018, pp. I71-183.

Alemany Bay, Carmen, «Casi un inédito hernandiano: 'El silbo de mal de ausencia'», Anales de Literatura Española, 6, 1988, pp. 13-31.

- «Presencias nerudianas en el proceso de creación y en algunos poemas de Miguel Hernández», en Quaderni ibero americani: Attualitá culturale della Penisola Iberica e dell'America Latina, 96, 2004, pp. 7-I9.

-. «Entre El rayo que no cesa y Viento del pueblo: más datos poéticos sobre el proceso de creación», Canelobre, 56, 2009-2010, pp. 92-105.

-. "Miguel Hernández tras las huellas del 27: octavas y décimas», en Un cósmico temblor de escalofríos. Estudios sobre Miguel Hernández, eds. Francisco Javier Díez de Revenga \& Mariano de Paco, Murcia, Fundación Cajamurcia, 20IO, pp. II-28. 
—. Miguel Hernández/I9Io-20Io. Actas del III Congreso Internacional, eds. Miguel Ángel Auladell \& José Luis Ferris, Alicante, Instituto Alicantino de Cultura Juan Gil-Albert, 2012.

- Miguel Hernández, el desafío de la escritura. El proceso de creación de la poesía hernandiana, Madrid, Visor, 2013.

—. «¿Cómo escribía Miguel Hernández sus poemas? Apuntes para descubrir un proceso creativo singular», en Para la libertad. Estudios sobre Miguel Hernández, eds. Juan Carlos Abril \& Luis García Montero, Jaén, Diputación de Jaén, 2018, pp.73-89.

—. «Reflexiones metapoéticas en esbozos inéditos de Miguel Hernández», Versants, 202I.

Alighieri, Dante, Tutte le opere, Roma, Newton, 1993.

Aullón de Haro, Pedro, «Las ideas teórico-literarias de Miguel Hernández», Miguel Hernández, cincuenta años después. Actas del I Congreso Internacional Miguel Hernández, Alicante, Universidad de Alicante/Comisión Homenaje a Miguel Hernández, I993, pp. 259-27I.

—. «La teoría explícita de Miguel Hernández», en Miguel Hernández: tradiciones y vanguardias, eds. Serge Salaün \& Javier Pérez, Alicante, Instituto de Cultura Juan Gil-Albert, I996, pp. 8I-84.

Aznar Soler, Manuel, «Miguel Hernández: ética y estética del comunismo», en Miguel Hernández: tradiciones y vanguardias, eds. Serge Salaün y Javier Pérez, Alicante, Instituto de Cultura Juan Gil-Albert, I996, pp. I45-I62.

—. «Miguel Hernández y el debate cultural de los años treinta (El poeta ante el Guernica)», Presente y futuro de Miguel Hernández. Actas del II Congreso Internacional Miguel Hernández, eds. Juan José Sánchez \& Francisco Esteve Ramírez, Orihuela, Fundación Cultural Miguel Hernández, 2004, pp. I2I-I37.

Balcells, José María, «Las poéticas de Miguel Hernández», Caligrama, Revista Insular de Filología, 3, I99I, pp. 69-90.

-. «Erotismos taurinos en El rayo que no cesa», en De mi corazón a mis asuntos. Asedios críticos sobre Miguel Hernández, ed. José María Balcells, Studia Iberica et Americana, 2, 2, 20I5, pp. 87-IO2, https://drive.google.com/file/d/oB3yYSsALoSnudUJFZEdnUHZVMjA/view [I4.02.202I].

Bécquer, Gustavo Adolfo, Poética, narrativa, papeles personales, ed. José María Guelbenzu, Madrid, Alianza Editorial, I970.

Bremond, Henri, La poésie pure, París, Grasset, 1926.

Cano Ballesta, Juan, La poesía de Miguel Hernández, Madrid, Gredos, I97I.

-. «Miguel Hernández y la crítica literaria (con dos textos olvidados)», Revista del Instituto de Estudios Alicantinos, enero, 1972, pp. I2-20.

—. «Miguel Hernández periodista en el frente y narrador épico», Miguel Hernández, cincuenta años después. Actas del I Congreso Internacional, Alican- 
te, Universidad de Alicante/Comisión Homenaje a Miguel Hernández, I993, pp. I23-I38.

—. "Miguel Hernández: la reflexión del poeta sobre el arte y la guerra», Miguel Hernández: tradiciones y vanguardias, eds. Serge Salaün \& Javier Pérez, Alicante, Instituto de Cultura Juan Gil-Albert, I996, pp. I35-I44.

Cano Ballesta, Juan \& Robert Marrast, Poesía y prosa de guerra y otros textos olvidados, Madrid, Hiperión, 1977.

Coro Montanet, Gleyvis, «La figura del soneto en la lógica de Miguel Hernández», en Presente y futuro de Miguel Hernández. Actas del II Congreso Internacional. Orihuela-Madrid, 26-30 de octubre de 2003, Orihuela, Fundación Cultural Miguel Hernández, 2004, pp. 259-266.

Deyermond, Alan, «The Death and Rebirth of Visigothic Spain in the Estoria de España», Revista Canadiense de Estudios Hispánicos, 9, 3, Primavera, I985, pp. 345-367.

Diego, Gerardo, «Perito en lunas», Cuadernos de Ágora, 49-50, I960, pp. 26-27.

Díez de Revenga, Francisco Javier, «El último Miguel Hernández: el regreso a la lírica popular y tradicional», en Para la libertad. Estudios sobre Miguel Hernández, eds. Juan Carlos Abril \& Luis García Montero, Jaén, Diputación de Jaén, 20i8, pp. 97-I34.

Ferris, José Luis, Miguel Hernández. Pasiones, cárcel y muerte de un poeta, Madrid, Temas de Hoy, 2002.

García Lorca, Federico, Obras completas, Madrid, Aguilar, I977a (vol. I) y I977b (vol. II).

García Montero, Luis, «El viento de la vida y Miguel Hernández», en Para la libertad. Estudios sobre Miguel Hernández, eds. Juan Carlos Abril \& Luis García Montero, Jaén, Diputación de Jaén, 2018, pp. I85-207.

Güntert, Georges, «El Quijote, 'El curioso impertinente' y la verdad de la literatura», Versants, 5I, 2006, pp. 20I-220.

Hernández, Miguel, Obra completa, Madrid, Espasa, 20Io, vols. I y II.

- Poesía completa, Madrid, Espasa Calpe, I992.

- Perito en lunas. El rayo que no cesa, ed. Agustín Sánchez Vidal, Madrid, Alhambra, 1976.

- Cancionero y Romancero de ausencias, ed. José Carlos Rovira, Alicante, Instituto Juan Gil Albert, 1985.

López Guil, Itzíar, «El "Romance de la luna, luna” y la teoría poética de Lorca», en Federico García Lorca, 75 años después, Versants, 57, 20II, pp. 9I-II4.

- Poesía religiosa cómico-festiva del Bajo Barroco español, Berna, Peter Lang, 201 .

—. "Del "romance de la luna, luna" al "Romance da lúa en Santiago"», Impossibilia, I2, 2016, pp. I2-47.

Martín, Eutimio, El oficio de poeta. Miguel Hernández, Madrid, Aguilar, 2010. 
Neruda, Pablo, «Sobre una poesía sin pureza», Caballo verde para la poesía, I, oct., I935a [p. 3].

—. «Los Temas», Caballo verde para la poesía, 2, nov., I935b [p. 3].

—. "Conducta y poesía», Caballo verde para la poesía, 3, dic., I935c [p. 3].

Rovira, José Carlos, Léxico y creación poética en Miguel Hernández, Alicante, Universidad de Alicante, 1983.

Scarano, Laura, «Identidad social e intimidad sentimental en las canciones de El hombre acecha de Miguel Hernández», Canelobre, 20I0, pp. I46-I6I.

Sijé, Ramón, «La ausencia del alma y del objeto (sonrisa y cólera en la poesía de Rafael Alberti)», El Gallo Crisis, 5 y 6, I935, pp. 4I-5I.

—. «La decadencia de la flauta», El Gallo Crisis, 5 y 6, I935, pp. 20-25.

- La decadencia de la flauta y el reinado de los fantasmas, Alicante, Instituto de Estudios Alicantinos, 1973.

Stauder, Thomas, «La amistad entre Pablo Neruda y Miguel Hernández», Escritural. Escritures d'Amerique latine, I, 2002, http://www.mshs.univ-poitiers.fr/crla/contenidos/ESCRITURAL/ESCRITURALI/NERUDA/ STAUDER/Stauder.html [26.0I.202I].

Urrutia, Jorge, «El modelo comunicativo de Viento del pueblo y El hombre acecha», en Miguel Hernández cincuenta años después: actas del I congreso internacional, ed. José Carlos Rovira, Alicante, Comisión del Homenaje a Miguel Hernández, I993, vol. I. pp. I55-I62.

-. «Leer a Miguel Hernández (Perito en lunas y el modelo comunicativo hernandiano)», en Presente y futuro de Miguel Hernández. Actas del II Congreso Internacional. Orihuela-Madrid, 26-30 de octubre de 2003, Orihuela, Fundación Cultural Miguel Hernández, 2004, pp. 95-Io6.

—. «Miguel Hernández, el hacedor de poemas», Ínsula, 763-764, julio, 20ı, pp. I-6. 